\title{
„BYŁ DALEKI OD NIENAWIŚCI, TAKŻE W STOSUNKU DO SWOICH OPRAWCÓW..." SPRAWA ADAMA GAJDKA JAKO PRZYKŁAD ZBRODNI KOMUNISTYCZNEJ
}

\author{
Ewa Rzeczkowska \\ Katolicki Uniwersytet Lubelski Jana Pawła II \\ Katedra Historii Najnowszej \\ The John Paul II Catholic University of Lublin \\ Department of Contemporary History \\ e-mail: ewrzeczkowska@gmail.com
}

Streszczenie. Adam Gajdek brał udział w kampanii polskiej we wrześniu 1939 r., walcząc w 3 Pułku Strzelców Podhalańskich w Bielsku. W 1940 r., przybrawszy pseudonim „Olek”, wstąpił do Związku Walki Zbrojnej, a następnie Armii Krajowej. Po wkroczeniu do Polski wojsk sowieckich pozostał w konspiracji. Brał udział m.in. w nieudanej akcji na więzienie w rzeszowskim zamku przeprowadzonej 7-8 października 1944 r. Na początku 1947 r. wstąpił do Zrzeszenia „Wolność i Niezawisłość”. W kwietniu 1947 r. objął funkcję kierownika organizacyjnego powstałej pod koniec 1946 r. siatki wywiadowczej o kryptonimie „Instytut Bakteriologiczny”, podlegając bezpośrednio kierownikowi Wydziału Informacji IV Zarządu Głównego WiN Mieczysławowi Kawalcowi. Aresztowany 17 października 1947 r. przez funkcjonariuszy Wojewódzkiego Urzędu Bezpieczeństwa Publicznego w Krakowie, przeszedł w tym mieście wstępne śledztwo, a następnie został przewieziony do aresztu Ministerstwa Bezpieczeństwa Publicznego w Warszawie. Jesienią 1948 r. jego sprawę skierowano do stołecznego Wojskowego Sądu Rejonowego. Wyrokiem z 23 października 1948 r. Adam Gajdek skazany został na karę śmierci. Naczelny Sąd Wojskowy oddalił skargę rewizyjną, a prezydent Bolesław Bierut nie skorzystał z prawa łaski, wobec czego 14 stycznia 1949 r. Adama Gajdka stracono w więzieniu przy ulicy Rakowieckiej w Warszawie.

Słowa kluczowe: Adam Gajdek, zbrodnie komunistyczne, stalinizm, Wolność i Niezawisłość. 
Ostatni raz, po pożegnaniu się w celi, widziałem Adama Gajdka 14 stycznia 1949 r., jak szedł spokojnym, równym krokiem, mając z prawej i lewej strony ludzi ubranych w polskie mundury wojskowe, podtrzymujących go, ale w sposób widoczny lekko, także trudno to było nazwać „prowadzeniem”. Spokojny jego chód i postawa przemawiały za tym, że się modlił, widać go było odwróconego do okien celi tyłem. Idący skręcili w prawo, znikli za murem budynku i po upływie około siedmiu sekund rozległ się pojedynczy strzał. Stojący w oknie celi żegnali się znakiem krzyża - Adam Gajdek już nie żył.

Tak ostatnie chwile życia Adama Gajdka wspominał Władysław Siła-Nowicki ${ }^{1}$, który spędził z nim dwa miesiące w celi śmierci mokotowskiego więzienia przy ulicy Rakowieckiej 37 w Warszawie. Gajdek został stracony 14 stycznia 1949 r. na mocy wyroku Wojskowego Sądu Rejonowego (dalej: WSR) w Warszawie. Jego śmierć jest przykładem zbrodni dokonanej przez funkcjonariuszy reżimu komunistycznego na osobie skazanej za działalność na rzecz niepodległego bytu państwa polskiego.

\section{UWAGI WSTĘPNE}

W tekście podjęto próbę opisania okoliczności zatrzymania Adama Gajdka przez funkcjonariuszy Urzędu Bezpieczeństwa, a przede wszystkim przebiegu śledztwa i postępowania sądowego, które toczyły się przeciwko niemu od jesieni 1947 do stycznia 1949 r. Celem nie było przedstawienie biografii Gajdka ani szczegółowe opisanie jego działalności w Zrzeszeniu „Wolność i Niezawisłość” (dalej: WiN), lecz ukazanie ostatnich miesięcy życia: od aresztowania, przez śledztwo i proces, do zamordowania w więzieniu na Mokotowie. W artykule zaprezentowano też niewielki wycinek działalności sieci wywiadowczej Obszaru Południowego WiN, który stanowi tło dla losów jednostki. Gajdek był bowiem jedną z dziesiątek osób zaangażowanych w działalność ogólnopolskiej sieci informacyjnej WiN, której komórka kierownicza mieściła się m.in. w Krakowie.

Podstawą źródłową artykułu jest dokumentacja Wojewódzkiego Urzędu Bezpieczeństwa Publicznego (dalej: WUBP) w Krakowie oraz Ministerstwa Bezpieczeństwa Publicznego w Warszawie (dalej: MBP) wytworzona tuż po aresztowaniu Gajdka i podczas prowadzonego przeciwko niemu śledztwa, a także dokumentacja powstała w czasie postępowania przed WSR w Warszawie i akta osobowe więźnia Adama Gajdka. Materiał archiwalny konfrontowany był z relacjami Ireny Cieślińskiej-Skrzypiec, Danuty Sochy-Jakubczyk, Ludwika Nalezińskiego oraz Władysława Siła-Nowickiego.

1 W. Siła-Nowicki, O Adamie Gajdku - wspomnienie, „Zeszyty Historyczne WiN-u”, 3(1993), s. 152. 
Znalazłszy się 17 października 1947 r. w areszcie WUBP w Krakowie, Gajdek podjął heroiczną walkę o swoje życie. W domu pozostawił siedmioletniego syna i ciężarną żonę. W trudnej, a dziś wiemy, że także beznadziejnej sytuacji, w jakiej się znalazł, początkowo podawał w zeznaniach fałszywe informacje o swoich danych personalnych i współpracownikach. W kolejnych miesiącach blisko rocznego śledztwa usiłował mówić jak najmniej. Przyjął strategię trzymania się faktów i przemilczania informacji obciążających siebie samego oraz współpracowników. Funkcjonariusze UB konfrontowali jednak jego zeznania z informacjami pozyskanymi w czasie działań operacyjnych od innych osób aresztowanych w sprawie. Dysponowali też bogatym zbiorem materiałów z archiwów WiN. Niektóre z zaprotokołowanych zeznań Gajdek odwoływał w czasie postępowania sądowego. Składane przez niego wyjaśnienia uzupełniano na podstawie przesłuchań innych osób związanych z siecią informacyjną WiN, której był członkiem² ${ }^{2}$ Część informacji na temat tej siatki konspiracyjnej przekazał funkcjonariuszom UB jego przełożony, Mieczysław Kawalec, aresztowany w lutym $1948 \mathrm{r}^{3}$

Zeznania Gajdka i innych aresztowanych w związku z wykryciem sieci wywiadowczej IV Zarządu Głównego WiN (dalej: ZG WiN) są relacjami w dużej części prawdziwymi. Konfrontowane ze sobą, w wielu miejscach pokrywają się lub uzupełniają. Z lektury dokumentacji śledztwa przeciwko Gajdkowi wynika,

2 W. Frazik, Siatki wywiadowcze Obszaru Poludniowego Zrzeszenia ,Wolność i Niezawistośc”, w: W sieci. Powojenne polskie siatki wywiadowcze (AK-NIE-DSZ-WiN, PSZ) w latach 1944-1955, Warszawa 2016, s. 290-296; T. Balbus, O Polskę Wolna i Niezawista (1945-1948). WiN w poludniowo-zachodniej Polsce (geneza - struktury - działalność - likwidacja - represje), Kraków-Wrocław 2004, s. 130-133.

3 Mieczysław Kawalec (1916-1951), ps. „Bronek”, „Iza”, „Kałuski”, „Lipowski”, „Psarski”, „Stanisławski”, „Żbik” - do końca grudnia 1945 r. był kierownikiem Wywiadu Rzeszowskiego Okręgu WiN. Po koniec 1945 r. przeniósł się z Krakowa do Zabrza. 1 III 1946 r. skierowany został przez Łukasza Cieplińskiego do komórki informacyjnej Obszaru Południowego WiN krypt. „Stomil”. Dotychczas pracował w komórce WiN krypt. „Spółdzielnia Praca”. Jego zadaniem było zorganizowanie w marcu i kwietniu 1946 r. pionu informacyjnego w Okręgu Krakowskim krypt. „Spółdzielnia Jedność" oraz wskazanie i przeszkolenie osoby, która pełniłaby funkcję kierownika tej struktury. Kawalec nie znalazł odpowiedniego człowieka, dlatego od maja (z datą wsteczną od marca) do października 1946 r. sam sprawował funkcję pierwszego zastępcy kierownika Okręgu WiN Kraków Wojciecha Szczepańskiego ps. „Teofil”. Był też kierownikiem Rejonu Południowego Okręgu Krakowskiego WiN. Na przełomie czerwca i lipca 1946 r. „Stomil” przemianowano na „Iskrę”, a od 1 września do połowy listopada 1946 r. jej kierownikiem był Stefan Sieńko ps. „Wiktor”. Po nim funkcję tę objął Kawalec. W styczniu 1947 r. wszedł w skład ścisłego kierownictwa IV Zarządu Głównego WiN jako kierownik zajmującego się wywiadem Oddziału Informacyjnego o kryptonimie „Instytut Bakteriologiczny”. W. Frazik, Siatki wywiadowcze..., s. 293-294; T. Balbus, O Polskę Wolna i Niezawista..., s. 129; ,,Wolność i Niezawistość” w dokumentach, t. 6: Cztery Zarzady Główne WiN przed sądami PRL. Noty biograficzne wazniejszych postaci wymienionych w tomach I-VI, cz. 2, oprac. A. Zagórski, Wrocław 2000, s. 305-306. 
że w zasadzie wszyscy świadkowie starali się go bronić. Czynił to także Kawalec i choć w protokołach z jego przesłuchań znajduje się wiele informacji obciążających Gajdka, to już podczas procesu sądowego Kawalec je podważał, biorąc odpowiedzialność za zarzucane mu czyny na siebie. Ustalenia śledztwa podważał też Gajdek, informując sąd, że śledczy zmuszali go do podpisywania protokołów. Szczegółowa analiza dokumentów ze śledztwa pokazuje jednak, że zarówno osoby przesłuchiwane w charakterze świadków, jak i sam Gajdek podawali informacje prawdziwe, choć nieprecyzyjne. W ich zeznaniach nie zgadzają się dni, miejsca spotkań i uczestniczące w nich osoby, a także kryptonimy. Niewątpliwie powodowało to chaos i mogło utrudniać pracę funkcjonariuszy śledczych, wpływając na przedłużanie śledztwa. Być może była to taktyka obliczona na zyskanie czasu, ale jak się okazało, nie przyczyniła się do uratowania Gajdkowi życia.

Historyk zajmujący się siatkami wywiadowczymi WiN i losami osób zaangażowanych w ich działalność skazany jest na korzystanie z tego rodzaju niejednoznacznych interpretacyjnie materiałów. Nieprawdziwe informacje znajdujące się w protokołach przesłuchań można jednak w znacznym stopniu wychwycić w oparciu o pozostałą dokumentację archiwalną, ustalenia innych badaczy, relacje i wspomnienia. Warto tu też zaznaczyć, że część zeznań składanych w czasie śledztwa przez osoby aresztowane różni się od relacji dawanych przez nie ponad czterdzieści lat później4. Niestety, większości z nich nie da się już zweryfikować. Wykorzystanie protokołów przesłuchań do badań nad dziejami powojennej konspiracji niepodległościowej wzbudzało dyskusje wśród historyków zajmujących się tym zagadnieniem ${ }^{5}$. Jedni, jak Tomasz Balbus czy Zbigniew Nawrocki, doceniali ich wartość źródłową, zwłaszcza informacyjną. Inni, np. Jerzy Kułak, patrzyli na nie krytycznie, twierdząc, że protokół przesłuchania jest najmniej wiarygodnym spośród wszystkich źródeł wytworzonych przez funkcjonariuszy UB, gdyż został sporządzony przez oficera śledczego, którego celem nie było wierne zapisywanie słów przesłuchiwanej osoby, lecz naginanie jej wypowiedzi w taki sposób, aby ją pogrążyćt. Należy się zgodzić z oboma tymi stanowiskami. Protokoły przesłuchań są cennym, a często jedynym źródłem, dzięki któremu możemy choć w części odtworzyć dzieje powojennej konspiracji niepodległościowej. Jeśli jest to możliwe, powinny być jednak konfrontowane z relacjami świadków, wspomnieniami, dokumentacją wytworzoną przez podziemie, a także z aktami operacyjnymi i administracyjnymi, które powstały

${ }^{4}$ Zob. przytoczone dalej relacje Ireny Cieślińskiej-Skrzypiec i Danuty Sochy.

5 Zob. zapis dyskusji, która odbyła się 17 X 2003 r. w redakcji czasopisma „Pamięć i Sprawiedliwość": Aparat bezpieczeństwa publicznego w walce z polskim podziemiem niepodległościowym, „Pamięć i Sprawiedliwość”, 1(2004), s. 56-58.

6 Tamże, s. 57. 
w wyniku działań funkcjonariuszy aparatu bezpieczeństwa. W takich przypadkach jak przedmiotowy tekst, którego głównym celem jest ukazanie przebiegu śledztwa i postępowania sądowego przeciwko osobie zaangażowanej w działalność niepodległościową, protokoły przesłuchań i dokumenty z akt kontrolno-śledczych są głównym materiałem źródłowym, którym powinien posłużyć się historyk. Z pewnością wykorzystanie dokumentacji operacyjnej i administracyjnej pokazałoby losy Gajdka z innej perspektywy, ale kwestia ta wykracza poza ramy i tak już obszernego artykułu. Wobec faktu, że wielu przedstawionych w tekście współpracowników kierowanej przez Kawalca sieci wywiadowczej zostało straconych lub zmarło, to właśnie dokumenty sądowe i kontrolno-śledcze obok nielicznych relacji umożliwiły odtworzenie ostatnich miesięcy życia Gajdka.

\section{KONSPIRACJA WOJENNA}

Adam Gajdek urodził się 7 kwietnia 1915 r. w Rzeszowie jako syn Franciszka i Zofii z domu Mikuła. W 1934 r. ukończył Szkołę Podoficerską Piechoty dla Małoletnich nr 3 w Nisku. Do 1939 r. służył w 3 Pułku Strzelców Podhalańskich w Bielsku7 , w szeregach którego w stopniu kaprala brał udział w kampanii polskiej $1939 \mathrm{r}$. W okresie okupacji niemieckiej mieszkał w Rzeszowie, gdzie prowadził sklep spożywczy przy ulicy Lwowskiej ${ }^{8}$. Zarówno jego miejsce pracy, jak i prywatne mieszkanie wykorzystywane były w czasie wojny jako skrzynka konspiracyjna rzeszowskiego Związku Walki Zbrojnej (dalej: ZWZ), a następnie Armii Krajowej (dalej: AK). W działalność polskiego podziemia zaangażowany był niemalże od pierwszych dni okupacji. Od 1940 r. pod pseudonimem „Olek” działał w ZWZ, a następnie AK. Po zajęciu Rzeszowa przez wojska sowieckie nadal pełnił funkcję skrzynki kontaktowej AK Rzeszów ${ }^{9}$. Jesienią 1944 r. razem z Eugeniuszem Szczepańskim ${ }^{10}$, Kazimierzem

7 Archiwum Instytutu Pamięci Narodowej w Warszawie [dalej: AIPN], 944/421, Akta sprawy Gajdka Adama, Protokół przesłuchania Adama Gajdka, sporządził: por. Romuald Pęcikiewicz, Kraków, 22 X 1947 r., k. 27.

8 I. Cieślińska-Skrzypiec „Myszka”, Aresztowanie, „Zeszyty Historyczne WiN-u”, 2(1992), s. 46.

9 Gajdek Adam, w: „Wolność i Niezawisłość” w dokumentach, t. 6, cz. 2, s. 174-175; J. Pisuliński, Adam Gajdek (1915-1949), w: Konspiracja i opór społeczny w Polsce 1944-1956. Stownik biograficzny, t. 2, Kraków-Warszawa-Wrocław 2004, s. 135.

${ }^{10}$ Prawdopodobnie chodzi o Eugeniusza Szczepańskiego ps. „Grudzień”. AIPN, 944/421, Akta sprawy Gajdka Adama, Protokół przesłuchania podejrzanego Adama Gajdka, sporządził: por. Roman Laszkiewicz, oficer śledczy MBP w Warszawie, Warszawa, 25 V 1948 r., k. 85-89; G. Ostasz, Okręg Rzeszowski Zrzeszenia ,Wolność i Niezawisłość”. Model konspiracji, struktura, dzieje, Rzeszów 2006, s. 383, przyp. 166. 
Dziekońskim ${ }^{11}$ i Władysławem Dzianną ${ }^{12}$ brał udział w kursie podchorążych, który odbywał się w jego mieszkaniu przy ulicy Grottgera. Egzamin przeprowadził Franciszek Błażej ${ }^{13}$, pełniący wówczas obowiązki zastępcy inspektora Inspektoratu Rzeszów $\mathrm{AK}^{14}$.

Gajdek brał udział w nieudanej próbie uwolnienia osadzonych w więzieniu na zamku w Rzeszowie ${ }^{15}$, podjętej przez AK w nocy z 7 na 8 października 1944 r. Był członkiem grupy dowodzonej przez Kawalca, którego poznał wiosną 1944 r. za pośrednictwem Szczepańskiego. Szczepański pracował w rzeszowskim więzieniu i dostarczał Gajdkowi meldunki o panującej tam sytuacji, a ten przekazywał je następnie Kawalcowi ${ }^{16}$. Po aresztowaniu Szczepańskiego oraz żony, Czesławy Gajdkowej, Gajdek zaprzestał działalności konspiracyjnej ${ }^{17}$. W październiku 1944 r. powołano go do „ludowego" Wojska Polskiego. W stopniu sierżanta pracował w rzeszowskiej Rejonowej Komendzie Uzupełnień (dalej: RKU), początkowo jako magazynier, a później podoficer gospodarczy. W styczniu 1945 r. został przeniesiony do RKU w Katowicach ${ }^{18}$.

Po rozwiązaniu AK Gajdek utrzymywał kontakt z żołnierzami, z którymi współpracował w okresie okupacji niemieckiej. W czerwcu 1945 r. spotkał na ulicy w Katowicach Błażeja i niedługo później gościł go w mieszkaniu przy ulicy Kościelnej w Katowicach, naprzeciwko RKU ${ }^{19}$. Błażej dwukrotnie korzystał z możliwości noclegu u Gajdka. Zeznał później, że w czasie jednej z wizyt, w sierpniu

${ }^{11}$ Kazimierz Dziekoński ps. „Orlik”, „Orlik II”, „Bruno” „Jan Przewłocki”. Zob. tamże, passim.

${ }^{12} \mathrm{NN}$.

${ }^{13}$ Biogram Franciszka Błażeja zob. Zrzeszenie „Wolność i Niezawistość” w dokumentach, t. 6, cz. 2, s. $54-56$.

${ }^{14}$ AIPN, 944/421, Akta sprawy Gajdka Adama, Protokół przesłuchania świadka Zbigniewa Bernatowicza, sporządził: por. Roman Laszkiewicz, oficer śledczy MBP w Warszawie, Warszawa, 3 VI 1948 r., k. 121-124; tamże, Protokół przesłuchania świadka Mieczysława Kawalca, sporządził: por. Roman Laszkiewicz, oficer śledczy MBP w Warszawie, Warszawa, 21 V 1948 r., k. 110-117; tamże, Protokół przesłuchania podejrzanego Adama Gajdka, sporządził: por. Roman Laszkiewicz, oficer śledczy MBP w Warszawie, Warszawa, 2 VI 1948 r., k. 94-101.

${ }^{15}$ Szerzej na temat więzienia w Rzeszowie zob. W. Bonusiak, Więzienie na Zamku w Rzeszowie w latach 1944-1956, „Studia Rzeszowskie”, 1(1995).

${ }^{16}$ AIPN, 944/421, Akta sprawy Gajdka Adama, Protokół przesłuchania podejrzanego Adama Gajdka, sporządził: por. Roman Laszkiewicz, oficer śledczy MBP w Warszawie, Warszawa, 25 V 1948 r., k. 85-89.

${ }^{17}$ Tamże, Protokół przesłuchania świadka Mieczysława Kawalca, sporządził: por. Roman Laszkiewicz, oficer śledczy MBP w Warszawie, Warszawa, 21 V 1948 r., k. 110-117.

1817 X 1947 r. powiedział w czasie przesłuchania, że do wojska zgłosił się dobrowolnie w pierwszych dnia września 1944 r. AIPN, 944/421, Akta sprawy Gajdka Adama, Protokół przesłuchania Adama Wilanowskiego (Adama Gajdka), sporządził: Franciszek Gałuszka, Kraków, 17 X 1947 r., k. 15.

${ }^{19}$ Od czerwca do października 1945 r. Błażej mieszkał w lokalu konspiracyjnym w Katowicach przy ulicy Zacisze 2. T. Balbus, O Polskę Wolnq i Niezawista..., s. 64. 
1945 r., w mieszkaniu przy Kościelnej obecni byli Adam Lazarowicz ${ }^{20}$ i Mieczysław Kawalec (pierwszego z nich Gajdek nie znał, natomiast drugiego znał bardzo dobrze). W lipcu lub sierpniu 1945 r. w mieszkaniu Gajdka odbyło się dwudniowe spotkanie konspiracyjne, na którym obecni byli: Łukasz Ciepliński² ${ }^{21}$, Franciszek Błażej, Władysław Piotrowski ${ }^{22}$, Jan Tataruch ${ }^{23}$, Antoni Stańko ${ }^{24}$, Józef Rzepka ${ }^{25}$, Stanisław Augustyn ${ }^{26}$, Kazimierz Pałka ${ }^{27}$ oraz prawdopodobnie Zbigniew Bernatowicz ${ }^{28}$. Dwudniową odprawę zorganizował i przeprowadził Błażej na polecenie Cieplińskiego ${ }^{29}$.

W sierpniu lub wrześniu 1945 r., widząc, że Gajdek często wyjeżdża w teren, Błażej zwrócił się do niego z prośbą, by przewiózł z Rzeszowskiego na Śląsk drukarnię. Gajdek powiedział, że zrobi to przy okazji najbliższego wyjazdu do Rzeszowa, po czym Błażej skontaktował go z Ludwikiem Nalezińskim ${ }^{30}$. W marcu 1946 r. przewieziono maszynę z Chmielnika Rzeszowskiego do Maciejowic koło Gliwic, gdzie przy ulicy Wolności 283 mieszkał podwładny Nalezińskiego z czasów okupacji niemieckiej, Stefan Mazur „Kwiatek”. W przeprowadzeniu tej operacji pomagał Gajdkowi brat Nalezińskiego, Czesław ${ }^{31}$.

${ }^{20}$ Adam Lazarowicz pełnił wówczas funkcję inspektora Inspektoratu Delegatury Sił Zbrojnych na Kraj w Rzeszowie. Jego biogram zob. Zrzeszenie „Wolność i Niezawisłość” w dokumentach, t. 6, cz. 2, s. $377-380$

${ }^{21}$ Biogram Łukasza Cieplińskiego zob. Z.K. Wójcik, Łukasz Ciepliński, w: Konspiracja i opór spoteczny..., s. 65-72.

${ }^{22}$ Biogram Władysława Piotrowskiego zob. Zrzeszenie „Wolność i Niezawisłość” $w$ dokumentach, t. 6, cz. 3, s. 529-530.

${ }^{23}$ Biogramy Jana Kazimierza Tatarucha zob.: T. Łaszczewski, Tataruch Jan Kazimierz, w: Małopolski słownik uczestników działań niepodległościowych, t. 9, red. T. Gąsiorowski i in., Kraków 2003, s. 176-179; T. Balbus, Jan Tataruch, w: Konspiracja i opór spoteczny..., s. 517-520; Z. Zblewski, Okreg Krakowski Zrzeszenia ,Wolność i Niezawistość” 1945-1948. Geneza, struktury, działalność, Kraków 2005, s. 104, przyp. 330.

${ }^{24}$ Antoni Stańko ps. „Pożoga”. Zob. A. Stańko, Gdzie Karpat progi... Armia Krajowa w powiecie dębickim, wyd. 2, Warszawa 1990.

${ }^{25}$ Biogram Józefa Rzepki zob. Zrzeszenie „Wolność i Niezawistość” w dokumentach, t. 6, cz. 3, s. 611614.

${ }^{26}$ Z. Zblewski, Okręg Krakowski..., passim.

${ }^{27} \mathrm{~W}$ dokumencie błędnie podano, że Pałka miał na imię Władysław. Biogram Kazimierza Pałki zob. Zrzeszenie ,Wolność i Niezawistość” $w$ dokumentach, t. 6, cz. 3, s. 505.

${ }^{28}$ Biogram Zbigniewa Bernatowicza zob. tamże, t. 6, cz. 2, s. 39-40.

${ }^{29}$ Szerzej na temat tego spotkania zob. Z. Zblewski, Okręg Krakowski.., s. 124-126.

${ }^{30}$ Ludwik Naleziński ps. „Antoni”, „Leszek”, „Marek”, „Ryś”, Roman Szwarc, Roman Mazurkiewicz. Od Błażeja otrzymał polecenie zorganizowania na terenie Obszaru Południowego wydawnictwa prasy konspiracyjnej. Zrzeszenie ,Wolność i Niezawistość” w dokumentach, t. 6, cz. 3, s. 464-468.

${ }^{31}$ AIPN, 944/421, Akta sprawy Gajdka Adama, Protokół przesłuchania świadka Franciszka Błażeja, sporządził: por. Roman Laszkiewicz, oficer śledczy MBP w Warszawie, Warszawa, 4 VI 1948 r., k. 125-128; tamże, Protokół przesłuchania podejrzanego Adama Gajdka, sporządził: por. Roman 


\section{DZIAŁALNOŚĆ W WIN}

Do WiN Adam Gajdek wstąpił najprawdopodobniej wczesną wiosną 1947 r. Zeznając w krakowskim UB, powiedział, że w lutym 1946 r. kilkakrotnie spotykał się w Katowicach z Mieczysławem Kawalcem, który miał go wówczas poinformować o istnieniu tej organizacji konspiracyjnej ${ }^{32}$. Kawalec zeznał z kolei, że w marcu lub kwietniu 1946 r. przeprowadził z Gajdkiem jednodniową odprawę w Katowicach przy ulicy Józefa Poniatowskiego 14 lub 16. Zapoznał go wtedy z materiałami polityczno-propagandowymi oraz założeniami i planami WiN. Gajdek sporządził w czasie tego spotkania notatki, które następnie zostawił w jednym z pokojów RKU w Katowicach. Zostały one znalezione przez sprzątających i - jak przypuszczał - oddane Informacji Wojskowej. Gajdek sądził zatem, że jest obserwowany przez oficerów RKU, a pod koniec września 1946 r. zaczął się obawiać aresztowania. Ostatecznie zdecydował się na przeprowadzkę do Krakowa, gdzie zamieszkał przy ulicy Zagrody $15 / 6$ pod fałszywym nazwiskiem Adam Wilanowski ${ }^{33}$. Kartę rozpoznawczą wyrobił mu prowadzący komórkę legalizacyjną w Krakowie Tadeusz Inglot ${ }^{34}$, a dostarczył Kawalec. Posługując się fałszywymi dokumentami, Gajdek szukał pracy. W styczniu lub lutym 1947 r. dostał ją w Biurze Plantacyjnym Cukrowni „Chybie” w Krakowie przy ulicy św. Gertrudy $8^{35}$.

Po zdezerterowaniu z wojska Gajdek poszukiwany był listem gończym, wystawionym 24 października 1946 r. przez wojskowego prokuratora 7 Łużyckiej Dywizji Piechoty ${ }^{36}$. W 1947 r. rozważał ujawnienie się przed organami bezpieczeństwa, na co nalegała rodzina. Od decyzji tej odwiódł go jednak Kawalec ${ }^{37}$. W Biurze Plantacyjnym Gajdek zarabiał około 2 tys. zł, co nie wystarczało na utrzymanie trzyosobowej rodziny. Kawalec dysponował wówczas pieniędzmi organizacyjnymi, ale jak twierdził na przesłuchaniu w maju 1948 r., nie mógł ich wypłacać w formie zasiłków,

Laszkiewicz, oficer śledczy MBP w Warszawie, Warszawa, 2 VI 1948 r., k. 94-101; L. Naleziński, Od „Na posterunku” do „Orta Biatego” (Refleksje i wspomnienia) cz. II, „Zeszyty Historyczne WiN-u”, 2(1992), s. 35; Ludwik Naleziński, w: Zrzeszenie „, Wolność i Niezawisłość” w dokumentach, t. 6, cz. 3, s. 465; T. Balbus, O Polskę Wolna i Niezawisłą.., s. 66.

${ }^{32}$ AIPN, 944/421, Akta sprawy Gajdka Adama, Protokół przesłuchania Adama Wilanowskiego (Adama Gajdka), sporządził: Franciszek Gałuszka, Kraków, 17 X 1947 r., k. 15-17.

${ }^{33}$ Tamże, Protokół przesłuchania Adama Gajdka, sporządził: por. Romuald Pęcikiewicz, Kraków, 22 X 1947 r., k. 35.

${ }^{34}$ Z. Zblewski, Okręg Krakowski..., s. 267-268.

${ }^{35}$ AIPN, 944/421, Akta sprawy Gajdka Adama, Protokół przesłuchania Adama Wilanowskiego (Adama Gajdka), sporządził: Franciszek Gałuszka, Kraków, 17 X 1947 r., k. 15-17.

${ }^{36}$ Tamże, Zapytanie o karalność, 20 XII 1947 r., k. 75-76.

${ }^{37}$ Tamże, Protokół przesłuchania Adama Gajdka, sporządził: por. Romuald Pęcikiewicz, Kraków, 22 X 1947 r., k. 27-41. 
a tylko za konkretną pracę na rzecz WiN. Zeznając tak, chciał pokazać, że Gajdek przystąpił do działalności konspiracyjnej zmuszony sytuacją materialną. W marcu lub kwietniu 1947 r., posługując się pseudonimami „Agata” lub „Antek”, rozpoczął pracę w kierowanej przez Kawalca sieci informacyjnej jako kierownik organizacyjny sieci wywiadowczej o kryptonimie „Instytut Bakteriologiczny”. Obowiązki wykonywał aż do dnia aresztowania w połowie października 1947 r. Ich szczegółowy zakres przedstawił w czasie jednego z przesłuchań w 1948 r. Kawalec. Do zadań Gajdka należało:

1. utrzymywanie kontaktu z „Biurem Doświadczeń” (przez łączniczkę Irenę Cieślińską ${ }^{38}$ ), „Oddziałem Zakaźnym” (przez łączniczkę Danutę Sochę ${ }^{39}$, z którą kontaktował się osobiście lub za pośrednictwem Cieślińskiej) oraz siecią terenową Kawalca (w tym przypadku kontaktował się z kierownikiem łączności Zbigniewem Bernatowiczem i jego łączniczkami);

2. prowadzenie kancelarii, w ramach czego zajmował się przepisywaniem pism zleconych mu przez Kawalca (robiły to też Irena Cieślińska i Maria Kozubowska), wysyłaniem poczty do „Biura Doświadczeń” i „Oddziału Zakaźnego” lub sieci terenowej, a poza tym prowadzeniem wspólnie z Kawalcem rachunkowości „Instytutu Bakteriologicznego";

3. utrzymywanie podręcznego archiwum, które początkowo przechowywane było w jego mieszkaniu, później w lokalu zajmowanym przez innego pracownika Biura Plantacyjnego Cukrowni „Chybie”, a pod koniec sierpnia 1947 r. - u znajomej Kawalca, Marii Susłowej, zatrudnionej w Spółdzielni Inżynieryjnej przy ulicy Piłsudskiego w Krakowie ${ }^{40}$.

W czasie procesu sądowego Kawalec powiedział natomiast, że do zadań Gajdka należało przygotowywanie i wysyłanie poczty do kierownictwa głównego WiN o kryptonimie „Biuro Doświadczeń”, przyjmowanie poczty z „Biura Doświadczeń” i podległych mu komórek organizacyjnych, jak „Oddział Zakaźny” i inne. Kierowany przez Kawalca „Instytut Bakteriologiczny” dysponował wydziałem organizacyjnym, kierownikiem łączności, łącznikami i maszynistką. „Oddział Zakaźny” był komórką zajmującą się opracowywaniem sprawozdań informacyjnych w oparciu o dostarczane przez niego materiały.

Materiały informacyjne zbierane przez sieć terenową - zeznawał Kawalec - były odnoszone na poszczególne punkty, skąd zabierali je łącznicy i doręczali je Bernatowiczowi. Równolegle

\footnotetext{
${ }^{38}$ Biogram Ireny Cieślińskiej zob. Zrzeszenie „Wolność i Niezawistość” $w$ dokumentach, t. 6, cz. 2, s. $124-126$.

${ }^{39}$ Biogram Danuty Sochy zob. tamże, t. 6, cz. 3, s. 647-648.

${ }^{40}$ AIPN, 944/421, Akta sprawy Gajdka Adama, Protokół przesłuchania świadka Mieczysława Kawalca, sporządził: por. Roman Laszkiewicz, oficer śledczy MBP w Warszawie, Warszawa, 21 V 1948 r., k. 110-117.
} 
do tej poczty wpływała do wydziału poczta od „Bogdana”41, zawierająca informacje z poszczególnych obszarów ${ }^{42}$.

W razie potrzeby przy wysyłaniu pism do „Biura Doświadczeń”, „Oddziału Zakaźnego" lub sieci terenowej Gajdek posługiwał się szyframi, z którymi zapoznał go Kawalec. Odszyfrowywał też niektóre pisma z „Biura Doświadczeń” do „Instytutu Bakteriologicznego”. Według zeznań Kawalca Gajdek mógł utrzymywać osobistą łączność z „Biurem Doświadczeń”, ponieważ miał ustalony kontakt uliczny z kierownikiem łączności Biura „Szymonem”, „Łucją”43.

Na początku 1947 r. Kawalec poznał Gajdka z przyszłymi współpracownikami w ramach sieci informacyjnej. W lutym w Biurze Plantacyjnym Cukrowni „Chybie” doszło do spotkania Gajdka z Cieślińską, którą znał z Rzeszowa ${ }^{44}$. Kawalec wyjaśnił, że będzie ona dostarczać i odbierać od niego pocztę. Tego samego miesiąca przy ulicy Franciszkańskiej w Krakowie zapoznał Gajdka z Sochą ${ }^{45}$. Wymiana korespondencji za pośrednictwem Gajdka rozpoczęła się w marcu 1947 r. Przesyłki dostarczano mu do pracy lub w czasie spotkań ulicznych. Na listach znajdowały się adnotacje: „Iza”, „BD”, „Zwoliński”, „Żurowski”, „Alfred”46. W marcu przy ulicy Stolarskiej w Krakowie Gajdek ponownie spotkał się z Sochą, by przekazać jej pocztę do Poznania lub Warszawy. Tego samego miesiąca na rogu ulic św. Jana i św. Tomasza lub św. Marka dostarczyła mu po powrocie przeznaczoną dla Kawalca pocztę konspiracyjną zaadresowaną do „Wojskowego Instytutu Geograficznego”. Do spotkania Gajdka z Sochą doszło jeszcze 5 lub 6 października 1947 r. w Krakowie, na ulicy Kościuszki. Odebrał od niej wówczas pocztę z „Oddziału Zakaźnego”47. W 1996 r. wspominała ona, że z Gajdkiem, Kawalcem i Bernatowiczem spotykała się jedynie

${ }^{41}$ Jeden z pseudonimów Łukasza Cieplińskiego (1913-1951), wówczas prezesa Zarządu Głównego WiN. Biogram zob. Zrzeszenie „,Wolność i Niezawisłość” $w$ dokumentach, t. 6, cz. 2, s. 115-117.

${ }^{42}$ AIPN, 944/421, Akta sprawy Gajdka Adama, Protokół rozprawy głównej przeciwko Adamowi Gajdkowi, Warszawa, 18 X 1948 r., k. 194-195.

${ }^{43}$ Chodzi o Józefa Stefana Szmida, który w 1947 r. pełnił funkcję kierownika działu łączności wewnętrznej IV Zarządu Głównego WiN i prowadził kancelarię ZG WiN. Zrzeszenie , Wolność i Niezawisłość" w dokumentach, t. 6, cz. 3, s. 697; AIPN, 944/421, Akta sprawy Gajdka Adama, Protokół przesłuchania świadka Mieczysława Kawalca, sporządził: por. Roman Laszkiewicz, oficer śledczy MBP w Warszawie, Warszawa, 21 V 1948 r., k. 110-117.

${ }^{44} \mathrm{~W}$ zeznaniu z 22 października Gajdek powiedział, że do spotkania doszło w jego mieszkaniu w Krakowie.

${ }^{45}$ Ona sama utrzymywała, że poznała Gajdka za pośrednictwem Cieślińskiej. D. Socha-Jakubczyk, Moja działalność w AK i WiN (1944-1948), „Zeszyty Historyczne WiN-u”, 9(1996), s. 107.

${ }^{46}$ AIPN, 944/421, Akta sprawy Gajdka Adama, Protokół przesłuchania Adama Gajdka, sporządził: por. Romuald Pęcikiewicz, Kraków, 22 X 1947 r., k. 35.

47 Tamże, Protokół przesłuchania podejrzanego Adama Gajdka, sporządził: por. Roman Laszkiewicz, oficer śledczy MBP w Warszawie, Warszawa, 2 VI 1948 r., k. 94-101. 
w czasie tzw. kontaktów ulicznych, kiedy przekazywała lub odbierała pocztę. Posługiwała się wówczas pseudonimem „Zakopiańska”. W obawie przed aresztowaniem w maju 1947 r. wyjechała z Krakowa do Gliwic, gdzie mieszkali jej rodzice ${ }^{48}$. W czerwcu tego samego roku miała się poddać operacji wyrostka robaczkowego. Zaświadczenie o przejściu tego zabiegu podpisane zostało pod datą 17 czerwca przez kierownika Poradni Sportowo-Lekarskiej w Krakowie dr. Wacława Sidorowicza, a następnie przedstawione przez Sochę na Wydziale Lekarskim Uniwersytetu Jagiellońskiego, gdzie studiowała wychowanie fizyczne. Nie wspominała, aby po wyjeździe do Gliwic pojawiała się w Krakowie. W październiku 1947 r. zamieszkała w Łodzi, gdzie rozpoczęła studia w Wyższej Szkole Gospodarstwa Wiejskiego. Jak twierdziła, zerwała wówczas kontakt organizacją i dopiero pod koniec grudnia lub na początku stycznia $1948 \mathrm{r}$. skontaktował się z nią Bernatowicz ${ }^{49}$.

Gajdek nawiązał kontakt z Bernatowiczem w maju lub czerwcu 1947 r. Do ich spotkania doszło na ulicy Piłsudskiego w Krakowie, za pośrednictwem Kawalca. Trzeba w tym miejscu wspomnieć, że od lipca do września 1946 r. w katowickim mieszkaniu Gajdka przebywała poszukiwana przez władze bezpieczeństwa siostra Bernatowicza, Bogumiła. Bernatowicz, podobnie jak Cieślińska, miał dostarczać i odbierać za pośrednictwem Gajdka przesyłki, wśród których były listy, paczki i pieniądze ${ }^{50}$.

W sierpniu lub we wrześniu 1947 r. za pośrednictwem Cieślińskiej Gajdek miał nawiązać kontakt z Józefem Szmidem. Cieślińska planowała wyjazd do Łodzi w celu podjęcia studiów. Po wyeliminowaniu jej jako łączniczki pomiędzy Gajdkiem a Szmidem miała zostać podjęta łącznośćs1. Ze względu na aresztowanie Szmida i następnie Gajdka nie doszło do nawiązania kontaktu.

\section{ARESZTOWANIE}

17 października 1947 r. funkcjonariusze WUBP w Krakowie aresztowali Adama Gajdka na moście Dębnickim, łączącym Stare Miasto i Zwierzyniec z Dębnikami ${ }^{52}$. W nocy z 16 na 17 października zatrzymano też Irenę Cieślińską - jego

${ }^{48} 13$ V 1947 r. została zdekonspirowana w wyniku działań operacyjnych funkcjonariuszy Sekcji II Wydziału III w Krakowie. T. Balbus, O Polskę Wolna i Niezawista..., s. 131-132.

${ }^{49}$ D. Socha-Jakubczyk, Moja działalność w AK $i$ WiN..., s. 108.

${ }^{50} \mathrm{~W}$ czasie wojny Bernatowicz pracował razem z Cieślińską w sklepie spożywczym firmy Vita w Rzeszowie, przy ulicy Gałęzowskiego. AIPN, 944/421, Akta sprawy Gajdka Adama, Protokół przesłuchania podejrzanego Adama Gajdka, sporządził: Roman Gładysek, Kraków, 18 X 1947 r., k. 21-26.

${ }^{51}$ Tamże, Protokół przesłuchania Adama Gajdka, sporządził: por. Romuald Pęcikiewicz, Kraków, 22 X 1947 r., k. 27-41; tamże, Protokół przesłuchania podejrzanego Adama Gajdka, sporządził: por. Roman Laszkiewicz, oficer śledczy MBP w Warszawie, Warszawa, 3 VI 1948 r., k. 102-105.

52 J. Pisuliński, Adam Gajdek..., s. 135. 
współpracowniczkę i łączniczkę WiN. Po latach we wspomnieniu opublikowanym w „Zeszytach Historycznych WiN-u” opisała ona dzień poprzedzający aresztowanie:

Do Krakowa przyjechałam rano - spotkanie z Józkiem ${ }^{53}$ miałam około południa [...] na Błoniach przed Akademikiem. Ciepły był wtedy październik, pełno młodzieży beztroskiej, śmiech, gwar na ulicy. Przyszłam punktualnie, ale nie widzę Józka, więc spaceruję sobie i naraz staje przede mną wysoki mężczyzna, prowadząc rower, i pyta: „Pani na mnie czeka?”. Odpowiedziałam, że nie, a wtedy on: „A na kogo?”. Chcąc, żeby się „odczepił”, powiedziałam, że na koleżankę, która jest w Akademiku. Pan nadal stał i powiedział: „Ta pani nie przyjdzie, proszę mi dać tę kopertę". Wtedy już się zorientowałam i nabrałam pewności, że to UB. Odpowiedziałam: „Pan chyba mnie bierze za kogoś innego. Pan się pomylił” i odeszłam ${ }^{54}$.

Po kilku godzinach kluczenia po mieście zdecydowała się zawiadomić o zdarzeniu Gajdków. Dotarła do ich mieszkania przy ulicy Zagrody, ale zastała tam jedynie Czesławę. Niedługo potem przyszedł Zbigniew Bernatowicz.

Zbyszek, zdenerwowany - wspominała - powiedział nam, że chyba coś się stało, bo cały most Dębnicki jest obstawiony i musiał iść okrężną drogą. Do Adama szło się właśnie przez ten most. Skonfrontowaliśmy moje zajście ze spostrzeżeniami Zbyszka i doszliśmy do przekonania, że coś koło naszej grupy się dzieje, coś jest niedobrze. [...] Adam nie wracał... Byliśmy niespokojni i podenerwowani. Pożegnaliśmy serdecznie Cesię, prosząc, by wszystko przekazała Adamowi, i oboje, dookoła, poza miastem, dostaliśmy się do Łagiewnik, gdzie przedtem mieszkałam ${ }^{55}$.

Mieszkanie Cieślińskiej w Łagiewnikach wynajmowała młoda dziewczyna, która pracowała z Gajdkiem w Biurze Plantacyjnym Cukrowni „Chybie”. Na miejscu okazało się, że funkcjonariusze UB urządzili tam kocioł i po kilku godzinach Cieślińska została zabrana do siedziby WUBP w Krakowie przy placu Inwalidów 4. Nie wiedziała jeszcze wówczas, że 8 października aresztowany został Szmid ${ }^{56}$, z którym miała się spotkać na krakowskich Błoniach ${ }^{57}$.

Zatrzymanie Szmida, Cieślińskiej i Gajdka miało związek z ujęciem 2 października 1947 r. prezesa Obszaru Południowego WiN Franciszka Błażeja ${ }^{58}$ i przechwyceniem przez UB jego podręcznego archiwum. Wśród skonfiskowanych rzeczy był kalendarz zawierający informacje o planowanych na październik i listopad spotkaniach

${ }^{53}$ Chodzi o Józefa Szmida.

${ }^{54}$ I. Cieślińska-Skrzypiec „Myszka”, Aresztowanie..., s. 45.

${ }^{55}$ Tamże, s. 46.

${ }^{56}$ Z. Zblewski, Okręg Krakowski..., s. 567.

57 Tamże, s. 48; L. Naleziński, Od „,Na posterunku” do „, Orła Białego”..., s. 37.

58 „Kapitulacja” Łukasza Cieplińskiego, oprac. W. Frazik, „Zeszyty Historyczne WiN-u”, 1920(2003), s. 401-402; Z. Zblewski, Okręg Krakowski..., s. 566. 
konspiracyjnych. Funkcjonariusze Sekcji II Wydziału III WUBP w Krakowie poznali ich daty i miejsca oraz nazwiska i pseudonimy kontaktów, a w mieszkaniu Błażeja urządzili na kilkanaście dni kocioł ${ }^{59}$. Z zeznań złożonych przez niego w czerwcu 1948 r. wynika, że z Gajdkiem spotkał się w czerwcu 1945 r. w Katowicach, a później widywali się w 1947 r. w Krakowie ${ }^{60}$. W aktach kontrolno-śledczych Gajdka znajduje się nieopatrzony datą wyciąg z zeznań Błażeja. W czasie przesłuchania, które odbyło się zapewne niedługo po jego aresztowaniu, podał dane personalne Gajdka, adres jego mieszkania w Katowicach oraz informację, że obecnie przebywa w Krakowie ${ }^{61}$.

Według Wojciecha Frazika zeznania Błażeja pozwoliły UB przygotować plan likwidacji Obszaru Południowego WiN. W wyniku ustaleń śledztwa dotyczącego jego osoby nastąpiło aresztowanie kierownika legalizacji Zygmunta Pawlusa ps. „Aleksy”. W dalszej kolejności funkcjonariusze UB uzyskali bardziej szczegółowe informacje na temat kierownika kancelarii i szefa łączności wewnętrznej IV ZG WiN Józefa Szmida „Łucji” oraz jego żony Marii Szmid „Maryli”, która była łączniczką i sekretarką kancelarii. Oboje zatrzymano 9 października 1947 r. Na podstawie zeznań Szmida UB dotarł do Cieślińskiej i Gajdka ${ }^{62}$. Jak oceniał Frazik, ,[t]ylko ich [Gajdka i Cieślińskiej - E.R.] heroicznej postawie można zawdzięczać, że wsypa nie przeniosła się na ten wydział [Wydział Informacji IV ZG - E.R.]"63.

17 października 1947 r., tuż po zatrzymaniu, Gajdek został przesłuchany przez funkcjonariusza WUBP w Krakowie ppor. Franciszka Gałuszkę. Wylegitymował się wtedy fałszywą kartą rozpoznawczą i przedstawił nieprawdziwy życiorys. Już w czasie pierwszego przesłuchania oprócz standardowej weryfikacji danych personalnych pytano go o działalność konspiracyjną po drugiej wojnie światowej. Utrzymywał, że nazywa się Adam Wilanowski i urodził się 4 lipca 1909 r. we Lwowie. Podał też nieprawdziwe dane swoich rodziców, przynależność do RKU oraz stosunek do służby wojskowej. Następnie zeznał, że w marcu lub lutym 1947 r. spotkał na ulicy w Krakowie Mieczysława Korańca ${ }^{64}$, znajomego z czasów zamieszkiwania

59 Tamże, s. 567; T. Balbus, O Polskę Wolna i Niezawista..., s. 74.

${ }^{60}$ AIPN, 944/421, Akta sprawy Gajdka Adama, Protokół przesłuchania świadka Franciszka Błażeja, sporządził: por. Roman Laszkiewicz, oficer śledczy MBP w Warszawie, Warszawa, 4 VI 1948 r., k. $125-128$.

${ }^{61}$ AIPN, 0259/234, Akta kontrolno-śledcze w związku z przynależnością do AK oraz WiN przeciwko Adam Gajdek-Wilanowski, Wyciąg z zeznań podejrzanego Błażej Franciszka ps. „Tadeusz” na osobę skompromitowaną w zeznaniach, sporządził: Władysław Czyż, oficer śledczy WUBP w Krakowie, k. 56.

${ }^{62}$ Kapitulacja” Łukasza Cieplińskiego..., s. 401.

${ }^{63}$ Tamże.

${ }^{64}$ W rzeczywistości chodziło o Mieczysława Kawalca. 
w Rzeszowie w 1942 r. Otrzymał od niego propozycję pracy w organizacji konspiracyjnej będącej przedłużeniem AK, na co wstępnie miał się zgodzić, ale kiedy dowiedział się, że będzie musiał wyjeżdżać w teren w celu dostarczania poczty organizacyjnej, ostatecznie odmówił. Koraniec miał mu wobec tego zaproponować prowadzenie skrzynki, za pomocą której zamierzano przekazywać pocztę organizacyjną, i na to Gajdek już przystał. Zapewne po to, aby zwiększyć wiarygodność swoich zeznań przed funkcjonariuszami UB, szczegółowo opowiadał o systemie przekazywania korespondencji konspiracyjnej, w której miał uczestniczyć jako tzw. skrzynka. Wspomniał też o Cieślińskiej, która przychodziła do jego mieszkania lub do miejsca pracy, tj. Biura Plantacyjnego Cukrowni „Chybie”. Pierwszą korespondencję dostarczono mu, jak zeznał, na początku marca 1947 r., a ostatnią przesyłkę przekazał 16 października ${ }^{65}$.

Pytany o adres zamieszkania Korańca, Gajdek odpowiedział, że go nie zna, stwierdzając jednocześnie, że jest on studentem prawa Uniwersytetu Jagiellońskiego ${ }^{66}$. Mówił, ile razy w miesiącu otrzymywał pocztę organizacyjną i do kogo adresowane były listy, ale ponieważ koperty były zalakowane, nie znał ich treści ${ }^{67}$. Zeznał też, że w konspiracji posługiwał się pseudonimem „Olek”, Koraniec występował jako „Iza” ${ }^{68}$, a Cieślińska - jako „Myszka”. Nie ujawnił stanowiska Korańca w organizacji, ale wspomniał, że wyjeżdżał on stale na Śląsk. Pytany o wynagrodzenie finansowe za działalność konspiracyjną, odpowiedział, że nie otrzymywał żadnych pieniędzy.

Zastanawiające jest, dlaczego, ukrywając tożsamość własną i Mieczysława Kawalca, Gajdek podawał prawdziwe imię, nazwisko i pseudonim Cieślińskiej. Być może zanim sam wpadł w ręce UB, wiedział już o jej zatrzymaniu. Zauważmy, że oprócz Cieślińskiej nie wskazał wówczas żadnej osoby, która współpracowałaby z nim w ramach sieci informacyjnej.

W pewnym momencie przesłuchanie zostało przerwane, a potem wznowione jeszcze tego samego dnia i przez tego samego oficera śledczego. Po przerwie Gajdek przyznał, że wcześniejsze zeznania były nieprawdziwe i podał swoje autentyczne dane personalne oraz adres zamieszkania. Można się domyślać, że funkcjonariusze WUBP dokładnie wiedzieli, z kim mają do czynienia, a wymyślona przez

${ }^{65}$ AIPN, 944/421, Akta sprawy Gajdka Adama, Protokół przesłuchania Adama Wilanowskiego (Adama Gajdka), sporządził: Franciszek Gałuszka, Kraków, 17 X 1947 r., k. 10-13.

${ }^{66}$ W latach 1935-1939 Kawalec studiował prawo na Uniwersytecie Jana Kazimierza we Lwowie, a po uzyskaniu stopnia magistra został przyjęty na stanowisko asystenta prof. Władysława Grabskiego. „Wolność i Niezawisłość" w dokumentach, t. 6, cz. 2, s. 305.

${ }^{67}$ AIPN, 944/421, Akta sprawy Gajdka Adama, Protokół przesłuchania Adama Wilanowskiego (Adama Gajdka), sporządził: Franciszek Gałuszka, Kraków, 17 X 1947 r., k. 10-14.

68 „Iza” to jeden z pseudonimów Kawalca. 
Gajdka historia wzbudziła w nich złość, którą następnie wyładowali na zatrzymanym. Z relacji innych osób, które miały wówczas kontakt z Gajdkiem, wiadomo, że śledczy stosowali wobec niego przemoc fizyczną. Choć nie ulega wątpliwości, że w czasie śledztwa był okrutnie bity, to pierwsze przesłuchanie mogło mieć inny przebieg. Początkowo ppor. Gałuszka, pełniący w tym czasie obowiązki zastępcy naczelnika Wydziału Śledczego WUBP w Krakowie, mógł pozwolić Gajdkowi na swobodną wypowiedź i dopiero po pewnym czasie - zorientowawszy się, że aresztowany mówi nieprawdę, choćby o swoich danych personalnych - przerwał przesłuchanie, dając mu do zrozumienia, że UB ma na jego temat szeroką wiedzę. W rękach funkcjonariuszy znajdowało się archiwum WiN skonfiskowane u Błażeja, a przed zatrzymaniem Gajdka aresztowano też przecież kilka osób, które go znały. Być może okazane mu dowody (choćby w postaci informacji z protokołów ich przesłuchań) spowodowały, że nie mógł już utrzymywać fałszywej wersji ${ }^{69}$.

W drugiej części przesłuchania Gajdek powiedział, że w 1943 r. poznał Mieczysława Kawalca ps. „Iza”, a w połowie lutego 1946 r. kilkakrotnie spotkał się z nim w Katowicach. Kawalec poinformował go wówczas o istnieniu konspiracyjnej organizacji WiN. Na początku 1946 r. w mieszkaniu Gajdka przy ulicy Kościelnej w Katowicach odbyło się zebranie konspiracyjne, on sam jednak, jak utrzymywał, miał nie brać w nim udziału. Wiosną 1946 r. przewoził paczki z Tyczyna w powiecie rzeszowskim do Zabrza ${ }^{70}$. Pod koniec maja u Gajdka zjawił się Kawalec i oświadczył, że może on zostać aresztowany przez UB, w związku z czym powinien natychmiast zwolnić się z pracy w katowickiej RKU. Kawalec miał mu dostarczyć nowe dokumenty osobiste. Dopiero po kolejnej jego wizycie w sierpniu tego roku i przekazaniu nowej karty rozpoznawczej na nazwisko Adam Wilanowski Gajdek zdecydował się przeprowadzić wraz z żoną do Krakowa ${ }^{71}$. W czasie przesłuchania podał adres mieszkania Kawalca, które miało znajdować się w Zabrzu przy ulicy Wolności 116, opisując i dokładnie rysując lokalizację kamienicy. Przedstawił również rysopis Kawalca i dość ogólnie scharakteryzował wygląd Bernatowicza ${ }^{72}$. Podając te informacje, Gajdek miał prawdopodobnie świadomość, że Kawalec

${ }^{69}$ AIPN, 944/421, Akta sprawy Gajdka Adama, Postanowienie WPR w Krakowie, Kraków, 27 XII 1947 r., k. 74.

${ }^{70}$ Być może Gajdek miał na myśli wspomniane tu wyżej przewiezienie drukarni z Chmielnika Rzeszowskiego do Maciejowic koło Gliwic w marcu 1946 r. W czasie przesłuchania opowiedział o tej operacji ogólnie, bez podawania szczegółów, zgodnie ze strategią trzymania się faktów, ale bez obciążania siebie samego i współpracowników.

${ }^{71}$ AIPN, 944/421, Akta sprawy Gajdka Adama, Protokół przesłuchania Adama Wilanowskiego (Adama Gajdka), sporządził: Franciszek Gałuszka, Kraków, 17 X 1947 r., k. 15-17.

${ }^{72}$ AIPN, 0259/234, Akta kontrolno-śledcze w związku z przynależnością do AK oraz WiN przeciwko Adam Gajdek-Wilanowski, Wyciąg z zeznań podejrzanego Gajdek Adama, Kraków, 17 X 1947 r., k. 66 . 
ukrywa się i na pewno nie przebywa w domu rodzinnym. Być może nawet zdążył już poinformować Gajdka o postanowieniach konferencji kadry kierowniczej WiN w Zakopanem, w której brał udział 10 października. W związku z aresztowaniami członków sieci konspiracyjnej podjęto wówczas decyzję o zawieszeniu kontaktów organizacyjnych oraz działalności WiN do czasu wyjaśnienia sprawy ${ }^{73}$.

W dniu zatrzymania Gajdka funkcjonariusze WUBP w Krakowie dokonali przeszukania w jego krakowskim mieszkaniu przy ulicy Zagrody $15 / 6$. W wyniku rewizji zabrano: 8597 zł, teczkę wiązaną marki Pelikan, odznakę PPS, dwa klucze, dwa spinacze, lusterko, rękawiczki skórkowe, krawat i pasek do spodni ${ }^{74}$. Tymczasowo aresztowany Adam Gajdek osadzony został w więzieniu karno-śledczym w Krakowie przy ulicy Montelupich ${ }^{75}$. Kolejne przesłuchania prowadził tam oficer WUBP w Krakowie Roman Gładysek ${ }^{76} .4$ grudnia aresztowany zeznał w czasie przesłuchania, że w jego mieszkaniu pozostała walizka, którą przechowywał u niego Kawalec. Ujawnił też, że w magazynie Biura Plantacyjnego Cukrowni „Chybie” znajduje się maszyna do pisania marki Erika oraz lampa do radia. Ponadto u pracownika biura Andrzeja Buczka miała się znajdować walizka, której zawartości Gajdek nie znał. W związku z tymi zeznaniami funkcjonariusze WUBP przeprowadzili rewizje w jego domu oraz miejscu pracy. Odnaleźli walizkę i książki ${ }^{77}$ oraz maszynę do pisania i lampę radiową ${ }^{78}$.

Między 22 października a 2 grudnia 1947 r. Gajdek nie był przesłuchiwany. Od 2 do 12 listopada przebywał w Wojskowym Szpitalu Okręgowym nr 5 w Krakowie (z dokumentacji szpitalnej wynika, że przyjęto go tam w związku z próbą samobójczą $\left.{ }^{79}\right)$. W kolejnych dniach, do 2 grudnia, był pod opieką lekarza więzienia przy Montelupich ${ }^{80}$. W karcie wypisowej ze szpitala czytamy, że trafił tam z ranami ciętymi warg, szyi, klatki piersiowej, obu nadgarstków i tętnicy łokciowej oraz ranami pod oboma kolanami ${ }^{81}$. Nie jest wcale oczywiste, że obrażenia te rzeczywiście były wynikiem próby targnięcia się Gajdka na własne życie ${ }^{82}$. Ich rodzaj

${ }^{73}$ Z.K. Wójcik, Mieczysław Marian Kawalec (1916-1951), w: Konspiracja i opór społeczny..., s. 216.

${ }^{74}$ AIPN, 944/421, Akta sprawy Gajdka Adama, Protokół rewizji, Kraków, 17 X 1947 r., k. 7.

75 Tamże, Postanowienie o tymczasowym aresztowaniu, Kraków, 18 X 1947 r., k. 18; tamże, Nakaz przyjęcia, Kraków, 18 X 1947 r., k. 19-20.

${ }^{76}$ Tamże, Protokół przesłuchania podejrzanego Adama Gajdka, sporządził: Roman Gładysek, Kraków 18 X 1947 r., k. 21.

77 Tamże, Protokół z rewizji, 4 XII 1947 r., k. 64.

78 Tamże, k. 65.

79 AIPN, Główna Komisja Ścigania Zbrodni przeciwko Narodowi Polskiemu, 919/2646, Akta personalne Adama Gajdka, Karta ambulatoryjna, k. 46.

${ }^{80}$ Tamże, Akta personalne Adama Gajdka, Karta ambulatoryjna, k. 46-48.

${ }^{81}$ Tamże, Karta wypisowa, 12 XI 1947 r., k. 45.

${ }^{82}$ O rzekomej próbie samobójczej Gajdka wspomina Wacław Sikorski, kierownika sieci informacyjnej „Marta” WiN (biogram zob. Zrzeszenie „,Wolność i Niezawistość” $w$ dokumentach, t. 6, cz. 2, s. 266269). W lipcu 1948 r. Sikorski był pracownikiem Departamentu WOP w Ministerstwie Obrony 
i liczba wskazują raczej, że jego celem mogło być samookaleczenie, a następnie trafienie do szpitala i zyskanie przerwy w śledztwie. Byłaby to więc strategia ukierunkowana na przetrwanie najtrudniejszego czasu po zatrzymaniu - tzw. śledztwa operatywnego ${ }^{83}$. Rozpoczynało się ono tuż po zatrzymaniu i najczęściej prowadzone było przez tych funkcjonariuszy operacyjnych UB, którzy dokonywali ujęcia. W na tym etapie osoba przesłuchiwana poddawana była silnej presji psychicznej i fizycznej. Stosując zastraszanie i bicie, śledczy usiłowali wydobyć z zatrzymanego jak najwięcej kontaktów pozwalających na dokonanie kolejnych aresztowań. Nie można oczywiście wykluczyć, że Gajdek doznał załamania psychicznego, które mogłoby prowadzić do próby samobójczej. Z analizy treści protokołów przesłuchań, a także jego postawy w kolejnych miesiącach śledztwa i podczas procesu przed sądem wynika jednak, że do końca usiłował walczyć o swoje życie.

Być może te dramatyczne wydarzenia wiązały się z wymuszeniem na nim zeznań, które miały doprowadzić UB do aresztowania Kawalca. W dokumentacji wytworzonej przez WUBP w Krakowie znajduje się sporządzony przez oficera śledczego Jana Zielińskiego protokół przesłuchania Gajdka datowany na 1 listopada $1947 \mathrm{r}^{84}$, w którym jego imię i nazwisko dopisano innym charakterem pisma

Narodowej. Zatrzymany został w związku z aresztowaniem jego wuja Władysława Jedlińskiego. Sikorskiego oskarżono o współpracę z wywiadem WiN. Początkowo przebywał w siedzibie MBP przy ulicy Koszykowej, a następnie trafił do mokotowskiego więzienia przy Rakowieckiej, osadzony w Oddziale 11 Pawilonu X - w celi, gdzie przebywał także Gajdek. W wywiadzie dla „Naszego Dziennika” udzielonym 9 III 2013 r. powiedział co prawda o próbie samobójczej Gajdka, ale trzeba zauważyć, że nie był bezpośrednim świadkiem wydarzeń, które miały miejsce w krakowskim więzieniu przy Montelupich. Być może to sam Gajdek utrzymywał wersję o próbie samobójczej, którą podnosił w czasie rozprawy sądowej, próbując wykorzystać ją jako argument w swojej obronie. Reprezentujący go adwokat Edmund Willner wnosił o powołanie biegłego lekarza psychiatry w celu zbadania oskarżonego pod kątem poczytalności, ale sąd wniosek odrzucił. W celi śmierci z „Zapora”, „Nasz Dziennik” [online], 9 III 2013 [dostęp: 28 V 2019], dostępny w internecie: $<$ https://naszdziennik.pl/polska-kraj/26272,w-celi-smierci-z-zapora.html>; AIPN, 944/421, Akta sprawy Gajdka Adama, Protokół rozprawy głównej przeciwko Adamowi Gajdkowi, Warszawa 18 X 1948 r., k. 187, 212-213.

${ }^{83}$ Śledztwo operatywne, nazywane też przesłuchaniem operatywnym, było pierwszą, intensywną fazą przesłuchiwania osoby aresztowanej tuż po jej zatrzymaniu. Jego celem było uzyskanie w możliwie krótki czasie maksymalnej liczby informacji przydatnych w dalszej pracy operacyjnej. Ł. Kamiński, Lingua securitatis, w: Wokót teczek bezpieki-zagadnienia metodologiczno-źródłoznawcze, red. F. Musiał, Kraków 2006, s. 396.

${ }^{84}$ Zieliński był doświadczonym oficerem śledczym. Między 10 III 1945 a 25 VI 1946 r. odbywał VI kurs dla oficerów śledczych w Centralnej Szkole MBP w Łodzi. W aparacie bezpieczeństwa pracował od 15 IX 1945 r. 28 VII 1949 r. otrzymał premię i pochwałę za udział w zlikwidowaniu oddziału „Wiarusy”, a 16 VIII - pochwałę i premię pieniężną „,W związku z wzorowym przeprowadzeniem śledztwa i przygotowaniem rozprawy ks. Gurgacza". Dane z katalogu funkcjonariuszy aparatu bezpieczeństwa: [Jan Zieliński], „Biuletyn Informacji Publicznej Instytutu Pamięci Narodowej” [online, dostęp: 28 V 2019], dostępne w internecie: <https://katalog.bip.ipn.gov.pl/informacje/103635>. 
i kolorem tuszu. Znajduje się tam przypisane Gajdkowi krótkie zeznanie, że 5 listopada 1947 r. o godzinie trzynastej lub piętnastej Cieślińska spotka się na ulicy Felicjanek z osobą z „Oddziału Zakaźnego”, która dostarczy paczkę dla Kawalca lub „Biura Doświadczeń”, a zatem Kawalec będzie wtedy w Krakowie i zgłosi się po tę paczkę do miejsca pracy Gajdka ${ }^{85}$. Funkcjonariusze krakowskiego UB usiłowali zapewne przygotować zasadzkę, jednak ostatecznie albo nie przyniosła ona zamierzonego skutku, albo w ogóle nie została zorganizowana. Do zatrzymania Kawalca doszło dopiero 1 lutego 1948 r. w Poroninie, a zeznania wymuszone na Gajdku w żaden sposób się do tego nie przyczyniły ${ }^{86}$. Po powrocie ze szpitala nadal wypytywany był o miejsce zamieszkania Kawalca, na co odpowiedział, że mieszka w Zabrzu i jest współwłaścicielem znajdującej się tam restauracji. Powiedział też, że Kawalec pochodzi z Trzciany koło Rzeszowa, gdzie się urodził ${ }^{87}$, i że nie zna ani jego krewnych, ani znajomych ${ }^{88}$.

Przesłuchanie operatywne Gajdka nakierowane było przede wszystkim na ustalenie miejsca pobytu Kawalca. Funkcjonariusze UB pytali go o związki z Kawalcem, okoliczności wstąpienia do WiN oraz pełnioną tam funkcję. Gajdek zeznawał, że prywatnie, bez związku z konspiracją, kontaktowali się od wiosny 1946 r. na terenie Katowic. W czasie jednego ze spotkań dostał propozycję zaangażowania się w działalność podziemia, ale nie był tym wtedy zainteresowany ${ }^{89} .2$ grudnia 1947 r. zeznał na przesłuchaniu, że pełnił w WiN funkcję pomocnika łączności i skrzynki kontaktowej, posługując się dwoma pseudonimami - „Olek” oraz „Agata” (ostatniego używał od stycznia 1947 r.). Od maja korespondencję dostarczał mu „Zbyszek”90. Latem tego roku paczki przekazywane były na ulicach Zwierzynieckiej i św. Marka w Krakowie, a odbierała je Danuta Socha - pośredniczka między Kawalcem a posługującym się pseudonimem „Olek” szefem „Oddziału Zakaźnego”, którego danych personalnych Gajdek nie ujawni ${ }^{91}$. Utrzymywał, że nie zna „Olka” i nigdy go nie widział. Mówił, że jego rolą było pomaganie w pracy Kawalcowi, a materiały z „Oddziału Zakaźnego” otrzymał pięciokrotnie (ostatni raz 5 lub 6 października),

${ }^{85}$ AIPN, 944/421, Akta sprawy Gajdka Adama, Protokół przesłuchania podejrzanego Adama Gajdka, sporządził: Jan Zieliński, Kraków, 1 XI 1947 r., k. 41.

${ }^{86}$ Zrzeszenie ,Wolność i Niezawisłość” w dokumentach, t. 6, cz. 2, s. 306; T. Balbus, O Polskę Wolna i Niezawista..., s. 76.

${ }^{87}$ Mieczysław Kawalec rzeczywiście urodził się w Trzcianie koło Rzeszowa.

${ }^{88}$ AIPN, 944/421, Akta sprawy Gajdka Adama, Protokół przesłuchania Adama Gajdka, sporządził: Franciszek Gałuszka, oficer śledczy WUBP w Krakowie, Kraków, 5 XII 1947 r., k. 67-71.

${ }^{89}$ Tamże, Protokół przesłuchania Adama Gajdka, sporządził: por. Romuald Pęcikiewicz, Kraków, 22 X 1947 r., k. 35.

${ }^{90}$ Chodzi o Zbigniewa Bernatowicza ps. „Zdzicha”.

${ }^{91}$ Chodzi o Stefana Sieńkę. 
za pośrednictwem Sochy oraz Cieślińskiej ${ }^{92}$. Zeznania Gajdka są jednak sprzeczne ze wspomnieniami Sochy, która twierdziła, że od maja 1947 r. przebywała poza Krakowem: najpierw u rodziców w Gliwicach, a po wakacjach - w Łodzi, gdzie zapisała się na studia i pracowała w sortowni owoców ${ }^{93}$.

Z Bernatowiczem spotykał się Gajdek nad Wisłą, koło mostu Dębnickiego i w kościele na placu Wszystkich Świętych; z Sochą natomiast na ulicy św. Marka lub św. Tomasza. Ujawnił też, że przekazywane mu dokumenty dotyczyły międzynarodowej i wewnętrznej sytuacji Polski. Były tam opracowania na temat Władysława Sikorskiego, Ignacego Daszyńskiego, Józefa Piłsudskiego, Romana Dmowskiego i Wincentego Witosa, które nazwał materiałami propagandowo-informacyjnymi. Pisma przekazywał Kawalcowi nad Wisłą lub w swoim mieszkaniu. Ten zaś pakował dokumenty i wysyłał do podległych mu oddziałów, adresując je do: „Drukarni”, „OZ”, „Połysku” „Szkoły Gospodarczej”, „Komendy Głównej BD” oraz „Alfreda”. Według zeznań Gajdka oddział kierowany przez Kawalca nosił nazwę „Instytut Bakteriologiczny", a zajmował się informacją i propagandą oraz gromadzeniem materiałów z życia politycznego, gospodarczego i administracji państwowej ${ }^{94}$.

18 grudnia 1947 r. na polecenie MBP Gajdek przewieziony został do Warszawy ${ }^{95}$. Osadzono go w X Pawilonie więzienia mokotowskiego, a 28 stycznia 1948 r. na wniosek Naczelnika II Wydziału Departamentu Śledczego MBP mjr. Adama Humera przetransportowano do aresztu wewnętrznego MBP przy ulicy Koszykowej. Razem z nim do Warszawy przekazana została także Cieślińska ${ }^{96} .9$ stycznia 1948 r. Gajdek przesłuchiwany był przez oficera śledczego MBP por. Jerzego Kędziorę w sprawie Bernatowicza. Powiedział, że pochodził on z województwa lwowskiego lub stanisławowskiego, a w czasie okupacji pracował w sklepie spożywczym przy ulicy Gałęzowskiego w Rzeszowie. Po raz pierwszy Gajdek zetknął się z Bernatowiczem na początku 1947 r., w pracy konspiracyjnej ${ }^{97}$. Bernatowicz był wtedy łącznikiem w „Instytucie Bakteriologicznym" i miał współpracować z Kawalcem w przygotowywaniu referatów, a także wykonywać dla niego specjalne zlecenia. Utrzymywał też kontakty z komórkami WiN o kryptonimach: „Szkoła Gospodarcza”, „Drukarnia”, „Czytelnik”, „Magazyn Społem” i „Połysk”. Według Gajdka Bernatowicz nie miał stałego miejsca

\footnotetext{
92 AIPN, 944/421, Akta sprawy Gajdka Adama, Protokół przesłuchania Adama Gajdka, sporządził: Franciszek Gałuszka, oficer śledczy WUBP w Krakowie, Kraków, 2 XII 1947 r., k. 44-48.

${ }^{93}$ D. Socha-Jakubczyk, Moja działalność w AK $i$ WiN..., s. 108.

${ }^{94}$ AIPN, 944/421, Akta sprawy Gajdka Adama, Protokół przesłuchania Adama Gajdka, sporządził: Roman Gładysek, oficer WUBP w Krakowie, Kraków 3 XII 1947 r., k. 50-63.

95 Tamże, Pismo do Wojskowej Prokuratury Rejonowej w Krakowie, [Kraków], 18 XII 1947 r., k. 73.

${ }^{96}$ Tamże, Postanowienie WPR w Krakowie, Kraków, 27 XII 1947 r., k. 74.

${ }^{97}$ Wcześniej zeznał, że poznał go w maju lub czerwcu 1947 r. Tamże, Protokół przesłuchania podejrzanego Adama Gajdka, sporządził: Roman Gładysek, Kraków, 18 X 1947 r., k. 21-26.
} 
zamieszkania ${ }^{98}$. W rzeczywistości urodził się w Radzyniu, a jego ojciec, Stefan, do 1937 r. był starostą w Bóbrce w województwie lwowskim, a od 26 lutego tego roku pełnił funkcję starosty rzeszowskiego. W lutym $1947 \mathrm{r}$. Zbigniew Bernatowicz nawiązał kontakt z Kawalcem, którego znał od 1945 r. Otrzymał od niego propozycję objęcia funkcji kierownika łączności Wydziału Informacji ZG WiN. Od lutego $1947 \mathrm{r}$. do 7 lutego 1948 r. był również p.o. kierownikiem organizacyjnego Wydziału Informacyjno-Wywiadowczego przy IV ZG WiN. Do jego zadań należało utrzymywanie łączności między komórkami wywiadowczymi na terenie całej Polski ${ }^{99}$.

Aresztowanie Gajdka było jednym z wielu, które między październikiem 1947 a lutym 1948 r. doprowadziły do likwidacji Zarządu Obszaru Południowego i IV ZG WiN. Centralne i obszarowe struktury zlikwidowano na przełomie listopada i grudnia tego roku, a kilka tygodni później przestał pracować pion informacyjny WiN. Aresztowanie jego kierownika Kawalca dokonane 1 lutego 1948 r. (według innych danych 29 stycznia) spowodowało zaprzestanie prób odbudowy ZG WiN ${ }^{100}$.

\section{ŚLEDZTWO}

Postępowanie śledcze przeciwko Adamowi Gajdkowi wszczęto formalnie 1 kwietnia 1948 r. ${ }^{101}$ Prowadził je por. Roman Laszkiewicz, który zyskał sobie opinię niezwykle brutalnego oficera śledczego MBP w Warszawie. O jego metodach śledczych pisała w latach dziewięćdziesiątych Danuta Socha:

[...] zostałam po raz pierwszy zbita w potworny, nieludzki sposób przez oprawcę Romana Laszkiewicza i od tego dnia bił mnie codziennie przez trzy miesiące pałką gdzie popadło i ręką po twarzy, żądając nazwisk i adresów członków AK i WiN-u oraz ich działalności, zwłaszcza w WiN-ie. Roman Laszkiewicz to sadysta, śmiał się, zadając ból fizyczny, psychiczny i moralny. Wysoki blondyn, lekko wyłupiaste, jasne oczy, duże wystające zęby. Mówił po polsku z akcentem rosyjskim. Torturował z premedytacją. [...] Podszedł blisko i obydwoma buciorami skoczył na moje stopy, niemal miażdżąc palce u nóg, paznokcie poschodziły. Często skręcał pasma moich włosów na swój palec i silnym szarpnięciem wyrywał ${ }^{102}$.

${ }^{98}$ Tamże, Protokół przesłuchania podejrzanego Adama Gajdka, sporządził: por. Jerzy Kędziora, oficer śledczy MBP w Warszawie, Warszawa, 9 I 1948 r., k. 77-78.

${ }^{99}$ Zrzeszenie „Wolność i Niezawisłość” $w$ dokumentach, t. 6, cz. 2, s. 39-40.

${ }^{100}$ W. Frazik, Siatki wywiadowcze..., s. 295-296.

${ }^{101}$ AIPN, 944/421, Akta sprawy Gajdka Adama, Postanowienie o wszczęciu śledztwa, Warszawa, 1 IV 1948 r., k. 81.

${ }^{102}$ D. Socha-Jakubczyk, List do Redakcji, „Zeszyty Historyczne WiN-u”, 7(1995), s. 262. Por. taż, ,Wygladasz jak Chrystus zdjęty z krzyża”, w: Zawołać po imieniu. Księga kobiet - więźniów politycznych 1944-1958, t. 1, oprac. B. Otwinowska, wsp. T. Drzal, Nadarzyn 1999, s. 125-126. 
Laszkiewicz przesłuchiwał zarówno Gajdka, jak i świadków w jego sprawie: Mieczysława Kawalca, Zbigniewa Bernatowicza, Danutę Sochę i Irenę Cieślińską. Gajdek ponownie opowiadał o swojej działalności konspiracyjnej w czasie okupacji niemieckiej i po zakończeniu wojny, m.in. o okolicznościach podjęcia współpracy z Kawalcem. Nowym wątkiem była kwestia wynagrodzenia za działalność konspiracyjną. 2 czerwca $1948 \mathrm{r}$. Kawalec zeznał w czasie przesłuchania, że w pierwszych miesiącach 1947 r. Gajdek miał otrzymywać od niego kwoty od 5 do 7 tys. zł, a od czerwca 1947 r. dostawał od 10 do 11 tys. zł wynagrodzenia za pracę konspiracyjną. Łącznie mogło to być ok. 60 tys. $z^{103}$. Przesłuchiwany na tę okoliczność Gajdek potwierdził 2 czerwca 1948 r., że od lutego do września 1947 r. otrzymał od Kawalca 57 lub 58 tys. zł za pracę konspiracyjną ${ }^{104}$. Kawalec ujawnił też stanowisko oraz zakres obowiązków Gajdka w WiN i scharakteryzował sieć jego kontaktów konspiracyjnych. W pozostałych kwestiach jego zeznania w dużej części zgadzały się z informacjami podanymi przez Gajdka. Pojawił się w nich także wątek planowanego rzekomo zamachu na szefa MBP Stanisława Radkiewicza ${ }^{105}$.

Bernatowicz potwierdził na przesłuchaniu zeznania Gajdka dotyczące jego działalności w okresie okupacji niemieckiej, a także okoliczności i czasu podjęcia współpracy z Kawalcem. Do konspiracji wciągnął Bernatowicza Kawalec, powierzając mu zadanie utrzymywania łączności w komórce o kryptonimie „Instytut Bakteriologiczny"106. Z Gajdkiem spotykał się 10, 11, 15 i 16 dnia każdego miesiąca na różnych ulicach w Krakowie ${ }^{107}$. Otrzymywał od niego przesyłki opisane

${ }^{103}$ AIPN, 944/421, Akta sprawy Gajdka Adama, Protokół przesłuchania świadka Mieczysława Kawalca, sporządził: por. Roman Laszkiewicz, oficer śledczy MBP w Warszawie, Warszawa, 2 VI 1948 r., k. 118-120.

${ }^{104}$ Tamże, Protokół przesłuchania podejrzanego Adama Gajdka, sporządził: por. Roman Laszkiewicz, oficer śledczy MBP w Warszawie, Warszawa, 2 VI 1948 r., k. 92-93.

${ }^{105}$ Tamże, Protokół przesłuchania świadka Mieczysława Kawalca, sporządził: por. Roman Laszkiewicz, oficer śledczy MBP w Warszawie, Warszawa, 21 V 1948 r., k. 110-117. Informacje o planowanych zamachach na dostojników komunistycznych wyjawił Kawalec w czasie przesłuchania prowadzonego przez Jerzego Kędziorę. Powiedział wówczas, że przy sieci wywiadowczej krypt. „Marta” została zorganizowana bojówka terrorystyczna, która w drugiej połowie 1947 r. miała dokonać zamachów na Władysława Gomułkę, Hilarego Minca, Jakuba Bermana, Stanisława Radkiewicza, Romana Zambrowskiego i Jerzego Albrechta. Kawalec zeznał też, że planowano porwania Minca, Bermana, Zambrowskiego i Albrechta, by następnie wymienić ich na aresztowanych członków KG WiN. Za uzyskanie tych informacji Kędziora otrzymał specjalne podziękowania od ministra bezpieczeństwa publicznego Radkiewicza. AIPN, 0193/5456, Akta osobowe Kędziora Jerzy, Raport dyrektora Departamentu Śledczego MBP płk. Józefa Różańskiego do Obywatela Ministra BP gen. dyw. St. Radkiewicza, Warszawa, 17 II 1948 r., k. 197-198.

${ }^{106}$ AIPN, 944/421, Akta sprawy Gajdka Adama, Protokół przesłuchania świadka Zbigniewa Bernatowicza, sporządził: por. Roman Laszkiewicz, oficer śledczy MBP w Warszawie, Warszawa, 3 VI 1948 r., k. 121-124.

${ }^{107}$ Inaczej zeznawał w tej sprawie Gajdek. Jego spotkania z Bernatowiczem miały się odbywać nad Wisłą, koło mostu Dębnickiego, i w kościele na placu Wszystkich Świętych. Tamże, Protokół 
kryptonimami: „Garbarnia Skór”, „Połysk”, „Czytelnik”, „Drukarnia”, „Magazyn Społem”, „Szkoła Gospodarcza” i ,Zakład Wulkanizacyjny”"108. W czerwcu 1947 r., podczas spotkania nad Wisłą Gajdek nauczył go posługiwania się szyfrem „Grodzisko". W lipcu 1947 r. Bernatowicz otrzymał od Gajdka materiały, które następnie doręczył w Częstochowie osobie posługującej się pseudonimem „Marcin”. Bernatowicz zeznał też, że w sierpniu 1947 r. przy ulicy Zagrody 15 w Krakowie odbyła się odprawa organizacyjna, którą prowadził Kawalec. Poza nimi dwoma byli na niej Gajdek i Cieślińska. Po raz ostatni spotkał się z Gajdkiem (któremu towarzyszyła wówczas Cieślińska) 16 października 1947 r. w Krakowie, na Dębnikach ${ }^{109}$. O odprawie organizacyjnej w domu Gajdków nie wspomina natomiast Cieślińska. Relacjonowała, że co prawda dotarła tam 16 października, ale zastała tylko żonę Adama, Czesławę. Wkrótce dołączył do nich zdenerwowany Bernatowicz, który stwierdził, że musiał iść okrężną drogą, bo most Dębnicki został obstawiony przez UB. Obawiał się o Gajdka, który wracał tamtędy do domu ${ }^{110}$.

Wiele nieścisłości jest też w zeznaniach Sochy. W czasie przesłuchania w lipcu 1948 r. powiedziała, że w Krakowie od 1947 do początku 1948 r. pełniła funkcję łączniczki WiN, posługując się pseudonimem „Zakopiańska”. Jej zadaniem było utrzymywanie łączności pomiędzy Kawalcem, Gajdkiem, „Adelą”"111, „Wiktorem”"12 i „Krynicką" ${ }^{113}$. Nie znała prawdziwego nazwiska Gajdka, a tylko jego pseudonim „Agata”. Po aresztowaniu przez UB rozpoznała go na okazanej kenkarcie na nazwisko Wilanowski ${ }^{114}$. Po raz pierwszy zetknęła się z Gajdkiem w lutym lub w marcu 1947 r. przy ulicy Franciszkańskiej w Krakowie. Skontaktował ich

przesłuchania Adama Gajdka, sporządził: Roman Gładysek, oficer śledczy WUBP w Krakowie, Kraków, 3 XII 1947 r., k. 50-63.

${ }^{108}$ Były to kryptonimy komórek WiN. Według Gajdka Bernatowicz utrzymywał kontakty z komórkami o kryptonimach: „Szkoła Gospodarcza”, „Drukarnia”, „Czytelnik” i „Magazyn Społem” lub „Połysk”. Tamże, Protokół przesłuchania podejrzanego Adama Gajdka, sporządził: por. Jerzy Kędziora, oficer śledczy MBP w Warszawie, Warszawa, 9 I 1948 r., k. 77-78.

${ }^{109}$ Tamże, Protokół przesłuchania świadka Zbigniewa Bernatowicza, sporządził: por. Roman Laszkiewicz, oficer śledczy MBP w Warszawie, Warszawa, 3 VI 1948 r., k. 121-124; tamże, Protokół przesłuchania Adama Gajdka, sporządził: Franciszek Gałuszka, oficer śledczy WUBP w Krakowie, Kraków, 2 XII 1947 r., k. 44-48; tamże, Protokół przesłuchania Adama Gajdka, sporządził: Roman Gładysek, oficer śledczy WUBP w Krakowie, Kraków, 3 XII 1947 r., k. 50-63.

${ }^{110}$ I. Cieślińska-Skrzypiec „Myszka”, Aresztowanie..., s. 45-46.

${ }^{111} \mathrm{NN}$.

${ }^{112}$ Chodzi o Stefana Sieńkę. Zrzeszenie ,Wolność i Niezawistość” $w$ dokumentach, t. 6, cz. 3, s. 697.

${ }^{113}$ Chodzi o Irenę Cieślińską.

${ }^{114}$ AIPN, 944/421, Akta sprawy Gajdka Adama, Protokół przesłuchania świadka Danuty Sochy, sporządził: kpt. Jan Karpiński, oficer śledczy MBP w Warszawie, Warszawa, 6 VII 1948 r., k. 129131; tamże, Protokół przesłuchania Adama Gajdka, sporządził: Franciszek Gałuszka, oficer śledczy WUBP w Krakowie, Kraków, 2 XII 1947 r., k. 44-48. 
Kawalec. Podczas ulicznego spotkania w Krakowie w październiku 1947 r. miała przekazać Gajdkowi pocztę organizacyjną, którą otrzymała od osoby o pseudonimie „Adela”"115. Jak już wspomniano, zeznania Sochy, złożone w lipcu 1948 r. nie zgadzają się z napisanymi w 1992 r. wspomnieniami, w których stwierdziła, że od maja do końca roku 1947 nie pracowała jako łączniczka ${ }^{116}$. Nie mogła zatem w październiku tego roku spotkać się z Gajdkiem w Krakowie.

W charakterze świadka w śledztwie przeciwko Gajdkowi Laszkiewicz przesłuchał też Cieślińską. Od października 1946 do aresztowania w połowie października 1947 r. pełniła ona funkcję łączniczki Kawalca i od niego otrzymywała też pensję za pracę w organizacji. Znała go od 1944 r., gdy jako jego łączniczka pracowała w Inspektoracie Rzeszów AK, gdzie rozwoziła pocztę do obwodów oraz placówek i przepisywała na maszynie materiały propagandowe. W 1946 r. zamieszkała w Krakowie ${ }^{117}$. Gajdka miała poznać w marcu 1947 r. za pośrednictwem Kawalca. Gdy spotkali się nad Wisłą, koło mostu Dębnickiego, przedstawił jej się jako Adam Wilanowski ps. „Olek”. Gajdek podał jej adresy swojego mieszkania przy Zagrody 15 oraz pracy przy św. Gertrudy $8^{118}$. Informacja ta jest nieprawdziwa, ponieważ Cieślińska znała Czesławę i Adama Gajdków jeszcze z czasów, gdy mieszkali w Rzeszowie. Wspominając w 1992 r. dzień 16 października 1947 r., napisała:

[...] muszę zawiadomić Adama i Cesię, z którymi byłam w serdecznych stosunkach - znaliśmy się jeszcze w Rzeszowie. Okrężną drogą, nawet nie wiedziałam kiedy, znalazłam się przed domem Adama. Umówiony znak w oknie w razie zagrożenia ostrzegał nas, że do domu wchodzić nie wolno. Tyle myśli kłębiło się po mojej głowie - parę minut spacerowałam po ulicy i zobaczyłam Cesię (żonę Adama) w oknie. Lżej mi się zrobiło i prędko weszłam do nich. Adama nie było $\mathrm{w}$ domu ${ }^{119}$.

Jako łączniczka Cieślińska otrzymywała od Gajdka paczki i pocztę. Widywała się z nim trzy lub cztery razy w miesiącu w jego miejscu pracy lub kościele ojców Dominikanów oraz przy moście Dębnickim. Wiosną 1947 r. przekazała „Olkowi”

\footnotetext{
${ }^{115}$ Tamże, Protokół przesłuchania świadka Danuty Sochy, sporządził: kpt. Jan Karpiński, oficer śledczy MBP w Warszawie, Warszawa, 6 VII 1948 r., k. 129-131. W 1996 r. Socha napisała, że po raz ostatni widziała Gajdka we wrześniu 1948 r., w czasie swojego procesu. Oprócz niego przesłuchiwano wówczas Kawalca i Bernatowicza: „Po raz ostatni widziałam pana Mieczysława Kawalca, Adama Gajdka i Zbigniewa Bernatowicza na mojej rozprawie w świetlicy więziennej. Wszyscy mnie bronili. To cisi Bohaterowie, o których nie można zapomnieć. Cześć Ich pamięci!!!”. D. Socha-Jakubczyk, Moja działalność w AK $i$ WiN..., s. 112.

${ }^{116}$ Tamże, s. 108.

${ }^{117}$ I. Cieślińska-Skrzypiec „Myszka”, Aresztowanie..., s. 43.

${ }^{118}$ AIPN, 944/421, Akta sprawy Gajdka Adama, Protokół przesłuchania świadka Ireny Cieślińskiej, sporządził: kpt. Jan Karpiński, oficer śledczy MBP w Warszawie, Warszawa, 7 VII 1948 r., k. 132-134.

${ }^{119}$ I. Cieślińska-Skrzypiec „Myszka”, Aresztowanie..., s. 45-46.
} 
maszynę do pisania, którą Kawalec powierzył jej na przechowanie. Latem „Olek” kilkakrotnie dawał jej do przepisywania na maszynie materiały propagandowe. We wrześniu skontaktowała go z Józefem Szmidem. Ostatni raz przed aresztowaniem spotkała się z Gajdkiem 16 października 1947 r. koło kina Wanda w Krakowie (co zgadza się z zeznaniami Bernatowicza). Otrzymała wówczas od niego list, który następnego dnia miała oddać Szmidowi pomiędzy mostem Dębnickim a parkiem Jordana ${ }^{120}$. We wspomnieniach napisała natomiast, że tego dnia nie spotkała się z Gajdkiem, ale z Kawalcem, i to od niego otrzymała pocztę dla Szmida. Rano przyjechała do Krakowa z Łodzi, a spotkanie ze Szmidem planowane było w godzinach południowych na Błoniach przed akademikiem ${ }^{121}$.

Śledztwo przeciwko Gajdkowi zamknięto 9 września 1948 r. ${ }^{122}$ Prowadzący je oficerowie byli wobec niego do tego stopnia brutalni, że z powodu obrażeń trafił do szpitala. Władysław Siła-Nowicki wspominał po latach:

[...] należał do legendarnych postaci Mokotowa. Wiadomym było, że przeszedł wyjątkowo okrutne i bezwzględne śledztwo i nie wydał nikogo. Był jednym z nieugiętych, niezłamanych do końca, jednym z ludzi, którzy podtrzymują wiarę w człowieka, w jego wewnętrzną moc i możliwości wytrzymania każdej męczarni i pozostania sobą do śmierci. Opowiadano o jego kamizelce, pokrytej od wewnątrz skorupą krwi, o tym jak przynoszono go ze śledztwa, bo nie był w stanie poruszać się o własnych siłach, i padał jak martwy, gdy skatowanego rzucano do celi ${ }^{123}$.

Mimo tak brutalnego postępowania funkcjonariuszy UB śledztwo w sprawie Gajdka nie przyniosło oczekiwanych rezultatów. O niezłomnej postawie Gajdka i Cieślińskiej świadczy notatka sporządzona w MBP trzy miesiące po ich aresztowaniu: „Aresztowani zaś »Olek« i »Myszka« do śledztwa prócz drobnych szczegółów nic istotnego nie wnieśli" "124.

Akt oskarżenia przeciwko Gajdkowi sporządzony został przez młodszego oficera śledczego MBP chor. Władysława Górę ${ }^{125}$, a następnie zatwierdzony przez

\footnotetext{
${ }^{120}$ AIPN, 944/421, Akta sprawy Gajdka Adama, Protokół przesłuchania świadka Ireny Cieślińskiej, sporządził: kpt. Jan Karpiński, oficer śledczy MBP w Warszawie, Warszawa, 7 VII 1948 r., k. 132134.

${ }^{121}$ I. Cieślińska-Skrzypiec „Myszka”, Aresztowanie..., s. 45.

${ }^{122}$ AIPN, 944/421, Akta sprawy Gajdka Adama, Postanowienie o zamknięciu śledztwa, 9 IX 1948 r., k. 151.

${ }^{123}$ W. Siła-Nowicki, O Adamie Gajdku..., s. 152.

${ }^{124}$ Cyt. za: W. Frazik, Operacja „Cezary”-przeglad wątków krajowych, w: „Zwyczajny” resort. Studia o aparacie bezpieczeństwa 1944-1956, red. K. Krajewski, T. Łabuszewski, Warszawa 2005, s. 401 , przyp. 8.

${ }^{125}$ Zob. dane z katalogu funkcjonariuszy aparatu bezpieczeństwa: [Władysław Góra], „Biuletyn Informacji Publicznej Instytutu Pamięci Narodowej” [online, dostęp: 28 V 2019], dostępne w internecie: $<$ https://katalog.bip.ipn.gov.pl/informacje/127675>.
} 
dyrektora Departamentu Śledczego MBP płk. Józefa Różańskiego i 27 września 1947 r. przez wiceprokuratora Naczelnej Prokuratury Wojskowej mjr. Zenona Rychlika. Postawiono mu siedem zarzutów:

I. W okresie od sierpnia 1944 r. do dnia zatrzymania go, tj. 17 października 1947 r., na terenie Polski w celu usunięcia przemocą Krajowej Rady Narodowej, Rządu Tymczasowego, Rządu Jedności Narodowej, a następnie Sejmu Ustawodawczego i Rządu RP, zagarnięcia ich władzy i zmiany ustroju Państwa Polskiego brał udział w nielegalnych związkach AK, a następnie „WiN”, przy czym działalność jego przejawiała się w tym, że w AK pełnił funkcję referenta obwodu Rzeszów oraz skrzynki pocztowej i występował pod pseudonimem „Olek”, w „WiN-ie” - kierownika organizacyjnego sieci wywiadowczej krypt. „IB”, [a] występował pod pseudonimem „Agata”, „Antek” [i] utrzymywał kontakty organizacyjne z kierownikami sieci wywiadowczej org. „WiN”: Maciołkiem ps. „Kazimierz”, Kawalcem Mieczysławem ps. „Iza”, kierownikiem łączności Komendy Głównej „WiN” Bernatowiczem Zbigniewem ps. „Bogusław”, łączniczką sieci wywiadowczej krypt. „IB” Cieślińską Ireną ps. „Myszka” i innymi, brał udział w odprawach organizacyjnych, na których były omawiane sprawy struktury organizacyjnej i dalsze wytyczne pracy konspiracyjnej, w szczególności odnośnie organizowania sieci wywiadowczej na terenie Polski.

II. W okresie od lipca 1944 r. do października 1944 r. na terenie woj. rzeszowskiego, działając na szkodę Państwa Polskiego, gromadził wiadomości stanowiące tajemnicę państwową i wojskową, jak też dotyczące obsady personalnej więzienia w Rzeszowie i stosunków w nim panujących i inne, które przekazywał kierownikowi wywiadu obwodu AK Rzeszów Kawalcowi ps. „Iza”, a następnie w okresie od lutego 1947 r. do dnia zatrzymania, tj. 17 października 1947 r., będąc urzędnikiem państwowym w Biurze Plantacji „Cukrowni Chybie” w Krakowie, pełnił funkcję kierownika organizacyjnego w sieci wywiadowczej Komendy Głównej „WiN” krypt. „IB”, gromadził wiadomości o wyżej określonych danych odnośnie sytuacji gospodarczej i politycznej w kraju, o obsadzie personalnej, ruchach i dyslokacji poszczególnych jednostek Wojska Polskiego, metodach pracy Urzędów Bezpieczeństwa Publicznego, które w formie raportów wywiadowczych przekazywał do Komendy Głównej org. „WiN” krypt. „BD”, wysyłał przez łączniczki będące do jego dyspozycji instrukcje wywiadowcze do terenowych sieci wywiadu org. „WiN”, wypłacał łącznikom sieci wywiadowczej „IB” pensje organizacyjne oraz pieniądze na koszta podróży do terenowych komórek wywiadowczych.

III. W okresie od sierpnia 1944 r. do dnia zatrzymania, tj. 17 października 1947 r., w związku z działalnością na szkodę Państwa opisaną w punkcie I i II przyjął dla siebie od szefa wywiadu org. „WiN” Kawalca Mieczysława działającego w interesie w interesie tzw. „emigracyjnego rządu” w Londynie około 70 tys. złotych.

IV. We wrześniu 1944 r. w Rzeszowie, jako członek grupy „AK” pod dowództwem Kawalca Mieczysława ps. „Iza” - „Żbik”, z bronią palną w ręku dopuścił się gwałtownego zamachu na więzienie w Rzeszowie, w wyniku czego zostało ciężko rannych kilku żołnierzy Wojska Polskiego.

V. W czasie wojny od sierpnia 1944 r. do listopada 1944 r. bez prawnego zezwolenia władzy przechowywał przy sobie pistolet „Walter” kal. 7,65 Nr 164194 wraz z amunicją.

VI. Jako st. sierżant pełniący funkcję oficera gospodarczego RKU Katowice w dniu 1 września 1946 r. celem trwałego uchylania się od pełnienia obowiązku wojskowego opuścił swoją jednostkę i pozostawał poza nią do dnia aresztowania, tj. 17 października 1947 r. 
VII. W okresie od września 1946 r. do dnia zatrzymania, tj. 17 października 1947 r., na terenie Polski posługiwał się fałszywą kartą rozpoznawczą na nazwisko Wilanowski Adam Nr 2197/43, używając jako autentycznej, na podstawie której uzyskał zaświadczenie Biura Plantacji „Cukrowni Chybie”, tymczasową legitymację PPS Nr 1504, legitymację ZZPHiB Nr 1169 i inne ${ }^{126}$.

Akt oskarżenia przeciwko Gajdkowi powstał w oparciu o wybrane wiadomości, wyselekcjonowane spośród danych, które udało się pozyskać w czasie śledztwa. Opierał się na informacjach wyłącznie obciążających oskarżonego - w dużej części zeznaniach Kawalca, których nie potwierdzali pozostali świadkowie. Oprócz dwóch przypadków, tj. dezercji z RKU w Katowicach oraz posługiwania się fałszywymi dokumentami, w śledztwie nie przedstawiono w sprawie Gajdka żadnych dowodów rzeczowych. Zarzucano mu gromadzenie objętych tajemnicą państwową i wojskową informacji o sytuacji gospodarczej i politycznej, dyslokacji wojska oraz metodach działania urzędu bezpieczeństwa, jednak podczas rewizji w jego mieszkaniu i miejscu pracy nie odnaleziono żadnych dokumentów, które potwierdzałyby taką działalność. Obrońca Gajdka, mec. Edmund Willner, podważył jeszcze szereg zarzutów przedstawionych w akcie oskarżenia, a następnie w zasadzie bez zmian uwzględnionych w wyroku sądu.

\section{PROCES}

Rozprawa przeciwko Adamowi Gajdkowi odbyła się w dniach 18-20 października 1948 r. przed WSR w Warszawie. Składowi sędziowskiemu przewodniczył kpt. Zbigniew Furtak, ławnikami byli sierż. Jan Kierbedź i sierż. Ryszard Kotwicki, a protokołował chor. Franciszek Żebrowski. W procesie nie uczestniczył prokurator wojskowy. Oskarżonego reprezentowali obrońcy - mec. Edmund Willner oraz mec. Edward Rettinger. W charakterze świadków wezwani zostali: Mieczysław Kawalec, Zbigniew Bernatowicz, Franciszek Błażej, Danuta Socha oraz Irena Cieślińska. Oskarżony Gajdek przedstawił swoją działalność konspiracyjną w czasie drugiej wojny światowej. Wspominał, że 1944 r. uczestniczył w próbie uwolnienia więźniów z zamku w Rzeszowie, zaznaczając jednak, że przydzielono go do grupy rezerwowej, która nie brała bezpośredniego udziału w akcji. Prostował też część zapisów z protokołów przesłuchań sporządzonych przez funkcjonariuszy UB. Mówił, że nie chciał ich podpisać bez uprzedniego przeczytania, ale został do tego

\footnotetext{
${ }^{126}$ AIPN, 944/421, Akta sprawy Gajdka Adama, Akt oskarżenia przeciwko Adamowi Gajdkowi, 10 IX 1948 r., k. 153-159. Akt oskarżenia znajduje się także innym zbiorze: AIPN, 0259/234, Akta kontrolno-śledcze w związku z przynależnością do AK oraz WiN przeciwko Adam Gajdek-Wilanowski, k. 9-15.
} 
zmuszony przez oficera śledczego. Gajdek bronił się, twierdząc, że jego rola w organizacji polegała jedynie na przekazywaniu korespondencji, której treści nie znał. Wszystkie listy przechodzące przez jego ręce, były bowiem zapieczętowane ${ }^{127}$.

Istotne znaczenie w procesie powinny mieć zeznania Kawalca, który starał się bronić Gajdka i umniejszać jego rolę w siatce konspiracyjnej. Przedstawiał go jako swojego podwładnego, który jedynie wykonywał polecenia, nie wykazując przy tym żadnej inicjatywy własnej. Podkreślał, że to za jego namową Gajdek przystąpił do konspiracji i opuścił jednostkę wojskową w Katowicach. Tłumaczył postępowanie swojego podwładnego jego ciężką sytuacją materialną oraz chorobą żony. Gajdek miał się zresztą uchylać od działalności konspiracyjnej, jednak Kawalcowi udało się go przekonać do jej podjęcia. W 1947 r. chciał się ujawnić, ale zwierzchnik z WiN uważał, że akcja ujawnieniowa służyła ujęciu osób będących w konspiracji. Kawalec tłumaczył, że Gajdek nie miał nawet świadomości, jaką funkcję przydzielono mu w konspiracji:

\begin{abstract}
Oskarżonemu przeznaczyłem funkcję kierownika organizacyjnego sieci wywiadowczej, względnie wydziału informacyjnego o kryptonimie „I[nstytut] B[akteriologiczny]”. Zaznaczam, że oskarżony nie znał swego stanowiska organizacyjnego ani charakteru swojego wydziału, gdyż oskarżonego w to nie wtajemniczałem. Zresztą oskarżony wypełniał tylko czynności zlecone przeze mnie i ja nie miałem potrzeby wtajemniczać go w szczegóły mojej pracy ${ }^{128}$.
\end{abstract}

Wyjaśniał też, że Gajdek mógł nie wiedzieć o realizowaniu przez „Instytut Bakteriologiczny" zadań o charakterze informacyjnym, gdyż do opracowywania otrzymywał wyłącznie materiały propagandowe: „Stwierdzam, że oskarżony sam nie zbierał żadnych wiadomości stanowiących tajemnicę państwową i takiego zadania w ogóle oskarżonemu nie dawałem, a praca oskarżonego w organizacji miała charakter czysto techniczny"129. Gajdek nie zajmował się też instrukcjami wywiadowczymi. Latem 1947 r. chciał nawet zakończyć działalność konspiracyjną, ale Kawalec odwiódł go od tej decyzji ${ }^{130}$. Wyjaśnienia te nie przekonały jednak składu orzekającego, który za bardziej wiarygodne uznał ustalenia poczynione w czasie śledztwa.

Wyrok w sprawie Gajdka ogłoszono 23 października 1948 r. Sąd skazał go z art. 86 par. 1 i 2 Kodeksu karnego Wojska Polskiego (dalej: KKWP) ${ }^{131}$ za

\footnotetext{
${ }^{127}$ AIPN, 944/421, Akta sprawy Gajdka Adama, Protokół rozprawy głównej przeciwko Adamowi Gajdkowi, Warszawa, 18 X 1948 r., k. 169-181.

${ }^{128}$ Tamże, k. 194.

${ }^{129}$ Tamże, k. 201.

${ }^{130}$ Tamże, k. 186-202.

${ }^{131}$ Dekret Polskiego Komitetu Wyzwolenia Narodowego z dnia 23 września 1944 r. - Kodeks karny Wojska Polskiego, Dz.U. 1944, nr 6, poz. 27.
} 
działalność w AK i przynależność do WiN w okresie od sierpnia 1944 do października 1947 r., z art. 15 par. 2 dekretu z 13 czerwca 1946 r. ${ }^{132}$ za gromadzenie wiadomości stanowiących tajemnicę państwową i wojskową, z art. 6 tego dekretu za działalność na szkodę państwa polskiego i przyjęcie środków finansowych od osoby działającej w interesie „,wrogich Państwu Polskiemu obcych ośrodków dyspozycyjnych", z art. 3.b dekretu o ochronie państwa ${ }^{133}$ za uczestnictwo w akcji na więzienie w Rzeszowie, $\mathrm{z}$ art. 4 par. 1.a tego dekretu za nielegalne posiadanie broni, z art. 115 par. $1 \mathrm{w}$ związku z art. 118 par. $1 \mathrm{KKWP}$ za uchylanie się od obowiązku wojskowego oraz z art. 181 Kodeksu karnego ${ }^{134}$ za posługiwanie się fałszywym dowodem tożsamości. Za dwa pierwsze przestępstwa Gajdek został skazany na karę śmierci, za pozostałe kara wynosiła zaś od 2 do 15 lat więzienia. W uzasadnieniu wyroku czytamy:

Sąd wziął pod uwagę dotychczasowe życie oskarżonego, jego charakter i stan rodzinny, czas i miejsce popełnienia przestępstw, długi okres pozostawania w nielegalnym związku „Win” [sic!] (od sierpnia 1944 r. do 25 października 1947 r.), okoliczność, że osk[arżo]ny nie skorzystał z dobrodziejstwa dwóch ustaw amnestyjnych, która dawała mu możność powrotu do normalnego życia, rodzaj i charakter stanowisk zajmowanych w przestępczym związku „Win”, pozostawanie w łączności ze związkiem o celach antypaństwowych w okresie odbywania służby wojskowej w charakterze podoficera gospodarczego w RKU, dopuszczenie się przestępstw, które przyniosły dużą szkodę interesom Państwa Polskiego, wreszcie duże napięcie złej woli osk[arżo]nego, który działał do dnia zatrzymania, wykazując wiele inicjatywy i ofiarności w ramach swej działalności przestępczej ${ }^{135}$.

Z przytoczonego fragmentu uzasadnienia wyroku wynika, że za okoliczność obciążającą sąd przyjął także dotychczasowe życie rodzinne Gajdka. Wbrew zeznaniom świadków i samego oskarżonego oraz obiektywnym faktom uznał, że Gajdek należał do WiN od sierpnia 1944 r., choć organizacja ta powstała ponad rok później, tj. 2 września 1945 r. Obrońca Gajdka, mec. Willner, dopatrzył się licznych nieprawidłowości w śledztwie i wykazał je w odwołaniu od wyroku sądu pierwszej instancji. 30 października 1948 r. złożył do Najwyższego Sądu Wojskowego skargę rewizyjną na wyrok warszawskiego WSR. W obszernym, liczącym dziesięć stron piśmie wskazywał przykłady naruszenia przez sąd prawa materialnego, tzn. za-

${ }^{132}$ Dekret z dnia 13 czerwca 1946 r. o przestępstwach szczególnie niebezpiecznych w okresie odbudowy Państwa, Dz.U. 1946, nr 30, poz. 192.

${ }^{133}$ Dekret Polskiego Komitetu Wyzwolenia Narodowego z dnia 30 października 1944 r. o ochronie Państwa, Dz.U. 1944, nr 10, poz. 50.

${ }^{134}$ Rozporzadzenie Prezydenta Rzeczypospolitej z dnia 11 lipca 1932 r. - Kodeks karny, Dz.U. 1932, nr 60, poz. 571.

${ }^{135}$ AIPN, 944/421, Akta sprawy Gajdka Adama, Wyrok w imieniu Rzeczypospolitej Polskiej, Warszawa, 23 X 1948 r., k. 223-224. 
kwalifikowania jednego stanu faktycznego do dwóch sankcji prawnych - art. 86 par. 1 i 2 KKWP oraz art. 7 w związku z art. 15 par. 2 dekretu z 13 czerwca 1946 r. Wbrew wynikom przewodu sądowego uznano, że Gajdek należał do WiN od sierpnia 1944 do 17 października 1947 r. WSR w ogóle nie wziął pod uwagę wyjaśnień oskarżonego i świadków, które w tej kwestii były zbieżne i wskazywały, że działalność Gajdka nie miała charakteru ciągłego, a od jesieni 1944 do wiosny 1947 r. w ogóle nie angażował się w pracę podziemia. Willner przypomniał też sądowi, że podczas procesu skazany zwracał uwagę na postępowanie funkcjonariuszy śledczych, którzy $\mathrm{w}$ trakcie śledztwa zmuszali go do podpisywania protokołów, których treści nie znał: ,[...] powołanie się Sądu pierwszego w tej materii na wyjaśnienia oskarżonego złożone w śledztwie nie wytrzymuje krytyki, skoro oskarżony na rozprawie twierdził, że do podpisywania nieodczytanych mu w śledztwie protokołów został zmuszony, a Sąd nie przeprowadził dowodów na obalenie tych twierdzeń oskarżonego" ${ }^{136}$. Co więcej, prokurator nie przedłożył w procesie żadnych dowodów rzeczowych, które potwierdzałyby zarzut gromadzenia przez oskarżonego dokumentów lub przedmiotów stanowiących tajemnicę państwową lub wojskową. Oskarżony nie przyznał się do tego czynu i nie potwierdzili go też zeznający w sprawie świadkowie. W podsumowaniu rewizji mec. Willner napisał: „Wszystkie okoliczności wyżej przytoczone wskazują dobitnie na to, że skazanie nastąpiło wbrew okolicznościom sprawy. Sąd pierwszy, wymierzając oskarżonemu najwyższy ustawowy wymiar kary, tj. karę śmierci, wziął pod uwagę jedynie okoliczności obciążające, ustalając, iż nie znajduje żadnych okoliczności łagodzących"137.

Najwyższy Sąd Wojskowy w składzie: ppłk Józef Dziowgo, ppłk Józef Warecki, ppłk Alfred Janowski oraz por. Jerzy Kwiatkowski jako protokolant z udziałem prokuratora Naczelnej Prokuratury Wojskowej Henryka Zelnika rozpatrzył skarge rewizyjną w sprawie Gajdka na posiedzeniu niejawnym 17 grudnia 1948 r. Jego decyzją skarga pozostawiona została bez uwzględnienia, a wyrok sądu pierwszej instancji - utrzymany w mocy ${ }^{138}$.

19 listopada 1948 r. osadzony w mokotowskim więzieniu Gajdek napisał do Bolesława Bieruta prośbę o ułaskawienie. Prezydent jednak z tego prawa nie skorzystał ${ }^{139}$. Pięć dni później, 14 stycznia 1948 r. o godzinie 19.40 Adam Gajdek został stracony w więzieniu na Mokotowie. Wyrok śmierci wykonano w obecności prokuratora Naczelnej Prokuratury Wojskowej ppłk. Czesława Szpądrowskiego,

\footnotetext{
${ }^{136}$ Tamże, Skarga rewizyjna, Warszawa, 30 X 1948 r., k. 233.

${ }^{137}$ Tamże, k. 236.

${ }^{138}$ Tamże, Postanowienie Najwyższego Sądu Wojskowego, Warszawa, 17 XII 1948 r., k. 249-252.

${ }^{139}$ Tamże, Prośba o ułaskawienie, Warszawa, 19 XII 1948 r., k. 256-261.
} 
naczelnika więzienia kpt. Alojzego Grabickiego, lekarza dr Stefanii Jabłońskiej ${ }^{140}$ oraz ks. mjr. Andrzeja Kamińskiego. Wyrok wykonał kat z Mokotowa st. sierż. Piotr Śmietański ${ }^{141}$.

W chwili śmierci Gajdek miał 33 lata. Nie zobaczył już nigdy trzech swoich synów: Zdzisława Ignacego, urodzonego 19 września 1940 r., oraz bliźniąt Adama i Ignacego, urodzonych 20 lutego 1948 r., już po aresztowaniu ojca. W czasie warszawskiego śledztwa przebywał w celi z płk. Bronisławem Banasikiem, który po latach opowiedział Władysławowi Siła-Nowickiemu, ,że przed rozprawą Adam Gajdek w paczce, która przyszła od żony, znalazł dwie zrośnięte ze sobą cebule i powiedział: »[O], żona daje mi znać, że urodziły się nam bliźnięta «142. I miał rację, choć oczy ojcowskie nigdy nie miały zobaczyć żadnego z dwóch chłopców"143. Czesława Gajdek o śmierci męża dowiedziała się nieoficjalnie w styczniu 1949 r., gdy nie przyjęto od niej paczki w okienku więzienia przy ulicy Rakowieckiej w Warszawie. Pismo z Naczelnej Prokuratury Wojskowej, w którym poinformowano ją o straceniu męża i pochowaniu go w zbiorowej mogile, otrzymała dopiero w 1956 r. ${ }^{144}$ Wraz z trójką małych dzieci została bez środków utrzymania. Zaopiekowali się nimi Władysława Kuczerowska i ks. Długosz z parafii św. Salwatora w Krakowie ${ }^{145}$.

\section{UNIEWAŻNIENIE WYROKU}

Spośród współpracowników Adama Gajdka, których wymieniono w artykule, stalinowskie więzienia przeżyły tylko Irena Cieślińska i Danuta Socha. Mieczysław Kawalec i Zbigniew Bernatowicz zostali straceni na mocy wyroków sądów stalinowskich. Na karę śmierci skazano też Józefa Szmida, lecz Bolesław Bierut skorzy-

\footnotetext{
${ }^{140} \mathrm{~W}$ opublikowanym przez Andrzeja Zagórskiego protokole $\mathrm{z}$ wykonania kary śmierci błędnie zapisano: „Stefania Jabłonka”. Wyrok Wojskowego Sądu Rejonowego w Warszawie z dnia 23 października 1948 r. skazujacy na karę śmierci Adama Gajdka, działacza Zrzeszenia ,,Wolność i Niezawistość” (Znak akt Sr. 1188/48), oprac. A. Zagórski, „Zeszyty Historyczne WiN-u”, 3(1993), dok. 4, s. 146-147.

${ }^{141}$ AIPN, 944/421, Akta sprawy Gajdka Adama, Protokół wykonania wyroku śmierci, k. 269. Biogram Piotra Śmietańskiego zob. S. Hermański, T. Wróblewski, Piotr Śmietański (1899-1950), kat z Mokotowa, „Aparat Represji w Polsce Ludowej 1944-1989”, 1(2012), s. 511-522.

${ }^{142}$ Po latach w wywiadzie dla „Naszego Dziennika” Ignacy Gajdek powiedział, że matka przesłała ojcu do więzienia paczkę, do której włożyła dwie cebule związane wstążką. Nie zdążył nas zobaczyć, „Nasz Dziennik” [online], 19 III 2014 [dostęp: 6 IV 2019], dostępny w internecie: <https:// naszdziennik.pl/polska-kraj/71772,nie-zdazyl-nas-zobaczyc.html>.

${ }^{143}$ W. Siła-Nowicki, O Adamie Gajdku..., s. 153.

${ }^{144}$ Pismo prokuratora Naczelnej Prokuratury Wojskowej do Czesławy Gajdek z 28 VI 1956 r. zob. Wyrok Wojskowego Sądu Rejonowego w Warszawie z dnia 23 października 1948 r..., dok. 5, s. 148.

${ }^{145}$ Zrzeszenie Wolność i Niezawistość w dokumentach, t. 6, cz. 2, s. 175.
} 
stał wobec niego z prawa łaski i karę śmierci zamienił na dożywotnie więzienie ${ }^{146}$. W 1992 r. na wniosek Zdzisława Gajdka wszczęto postępowanie sądowe w sprawie unieważnienia wyroku WSR w Warszawie z 23 października 1948 r., skazującego jego ojca, Adama, na karę śmierci. W uzasadnieniu postanowienia z 30 marca 1993 r. Sąd Warszawskiego Okręgu Wojskowego napisał:

W ocenie Sądu wszystkie przypisane wyrokiem Adamowi Gajdkowi czyny były związane z jego działalnością organizacyjną. Działalność ta w ramach struktur „AK” zmierzała do odzyskania przez państwo Polskie niepodległego bytu. [...] pan Adam Gajdek [...] pozostał wierny wyznawanym niepodległościowym ideom. Realizował je w powstałej we wrześniu 1945 r. postakowskiej organizacji „Wolność i Niezawisłość”, działając w jej strukturach aż do dnia zatrzymania, tj. 17.10.1947 r. „WiN”, łącząca przyszłość Polski z jej legalnym emigracyjnym rządem londyńskim, występowała przeciwko totalitarnemu, niedemokratycznemu systemowi narzuconemu Polsce przez Związek Socjalistycznych Republik Radzieckich. Dlatego nie ulega żadnej wątpliwości, że wszystkie przypisane Adamowi Gajdkowi czyny były związane z jego działalnością na rzecz niepodległego, suwerennego i podmiotowego bytu Państwa Polskiego ${ }^{147}$.

Pełnomocnikiem Zdzisława Gajdka w sprawie o unieważnienie wyroku był mec. Władysław Siła-Nowicki. W połowie stycznia 1949 r. obaj przebywali w celi śmierci mokotowskiego więzienia przy ulicy Rakowieckiej w Warszawie. Siła-Nowicki żegnał wówczas Adama Gajdka idącego na śmierć. „Była w Adamie Gajdku jakaś siła szczególna - wspominał - chyba płynąca również z jego głębokiej wiary. Był daleki o nienawiści, także w stosunku do swoich oprawców"148. Po ponad czterdziestu latach od tego wydarzenia doprowadził do unieważnienia wyroku śmierci wydanego przez stalinowski sąd na człowieka całkowicie niewinnego.

W 1993 r. synowie Adama Gajdka: Zdzisław, Adam i Ignacy złożyli wniosek o odszkodowanie i zadośćuczynienie z tytułu represjonowania ich ojca. 17 czerwca 1993 r. postanowieniem Sądu Warszawskiego Okręgu Wojskowego na sesji wyjazdowej w siedzibie Wojskowego Sądu Garnizonowego w Krakowie na mocy art. 8 ust. 1 i 2 oraz art. 13 ustawy z 23 lutego 1991 r. ${ }^{149}$ każdy z braci otrzymał

\footnotetext{
${ }^{146}$ Tamże, t. 6, cz. 3, s. 697-698.

${ }^{147}$ AIPN, 944/421, Akta sprawy Gajdka Adama, Postanowienie Sądu Warszawskiego Okręgu Wojskowego z 30 III 1993 r., k. 290.

${ }^{148}$ W. Siła-Nowicki, O Adamie Gajdku..., s. 152.

${ }^{149}$ Ustawa z dnia 23 lutego 1991 r. o uznaniu za nieważne orzeczeń wydanych wobec osób represjonowanych za działalność na rzecz niepodległego bytu Państwa Polskiego, Dz.U. 1991, nr 34, poz. 149. Zob. także Ustawa z dnia 20 lutego 1993 r. zmieniajaca ustawę o uznaniu za nieważne orzeczeń wydanych wobec osób represjonowanych za działalność na rzecz niepodległego bytu Państwa Polskiego, Dz.U. 1993, nr 36, poz. 159.
} 
$192 \mathrm{mln}$ zł tytułem odszkodowania za poniesioną szkodę oraz $70 \mathrm{mln}$ zł tytułem zadośćuczynienia za doznaną krzywdę

Szczątki Adama Gajdka odnaleziono latem 2012 r. w kwaterze „L” Cmentarza Wojskowego na Powązkach w Warszawie. 28 lutego 2014 r., w przeddzień Narodowego Dnia Pamięci Żołnierzy Wyklętych, odbyła się w Belwederze uroczystość z udziałem prezydenta RP Bronisława Komorowskiego, w czasie której Ignacy Gajdek odebrał notę identyfikacyjną swojego ojca ${ }^{151} .7$ września $2015 \mathrm{r}$. szczątki Adama Gajdka uroczyście pochowano w Panteonie - Mauzoleum Wyklętych-Niezłomnych na Cmentarzu Wojskowym na Powązkach. 1 marca 2016 r., w Narodowym Dniu Pamięci Żołnierzy Wyklętych, Adam Gajdek awansowany został pośmiertnie do stopnia podporucznika.

BIBLIOGRAFIA

\section{ŹRÓDŁA ARCHIWALNE}

\section{Archiwum Instytutu Pamięci Narodowej w Warszawie}

Akta sprawy Gajdka Adama, sygn. 944/421.

Akta kontrolno-śledcze w związku z przynależnością do AK oraz WiN przeciwko Adam Gajdek-Wilanowski, sygn. 0259/234.

Akta personalne więźnia Adama Gajdka, sygn. AIPN GK 919/2646.

Akta osobowe Kędziora Jerzy, sygn. 0193/5456.

\section{ŹRÓDŁA DRUKOWANE}

Cieślińska-Skrzypiec I. „Myszka”, Aresztowanie, „Zeszyty Historyczne WiN-u”, 2(1992).

Dekret Polskiego Komitetu Wyzwolenia Narodowego z dnia 23 września 1944 r. - Kodeks karny Wojska Polskiego, Dz.U. 1944, nr 6, poz. 27.

Dekret Polskiego Komitetu Wyzwolenia Narodowego z dnia 30 października 1944 r. o ochronie Państwa, Dz.U. 1944, nr 10, poz. 50.

Dekret z dnia 13 czerwca 1946 r. o przestępstwach szczególnie niebezpiecznych w okresie odbudowy Państwa, Dz.U. 1946, nr 30, poz. 192.

[Jan Zieliński], „Biuletyn Informacji Publicznej Instytutu Pamięci Narodowej” [online, dostęp: 28 V 2019], dostępny w internecie: <https://katalog.bip.ipn.gov.pl/informacje/103635>.

\footnotetext{
${ }^{150}$ AIPN, 944/421, Akta sprawy Gajdka Adama, Postanowienie Sądu Warszawskiego Okręgu Wojskowego na sesji wyjazdowej w siedzibie Wojskowego Sądu Garnizonowego w Krakowie, Kraków, 17 VI 1993 r., k. 291-292.

${ }^{151}$ N. Nowotnik, Święto „Żotnierzy Wyklętych” - kolejny powrót bohaterów, „Kombatant”, 3(2014), s. 8-9.
} 
Naleziński L., Od „Na posterunku” do „Orta Białego” (Refleksje i wspomnienia) cz. II, „Zeszyty Historyczne WiN-u", 2(1992).

Nie zdążył nas zobaczyć, „Nasz Dziennik” [online], 19 III 2014 [dostęp: 6 IV 2019], dostępny w internecie: <https://naszdziennik.pl/polska-kraj/71772,nie-zdazyl-nas-zobaczyc.html>.

Rozporzadzenie Prezydenta Rzeczypospolitej z dnia 11 lipca 1932 r. - Kodeks karny, Dz.U. 1932, nr 60, poz. 571.

Siła-Nowicki W., O Adamie Gajdku - wspomnienie, „Zeszyty Historyczne WiN-u”, 3(1993).

Socha-Jakubczyk D., List do Redakcji, „Zeszyty Historyczne WiN-u”, 7(1995).

Socha-Jakubczyk D., Moja działalność w AK i WiN (1944-1948), „Zeszyty Historyczne WiN-u”, 9(1996).

Socha-Jakubczyk D., , Wyglądasz jak Chrystus zdjęty z krzyża”, w: Zawołać po imieniu. Księga kobiet - więźniów politycznych 1944-1958, t. 1, oprac. B. Otwinowska, wsp. T. Drzal, Nadarzyn 1999.

Ustawa z dnia 23 lutego 1991 r. o uznaniu za nieważne orzeczeń wydanych wobec osób represjonowanych za działalność na rzecz niepodległego bytu Państwa Polskiego, Dz.U. 1991, nr 34, poz. 149.

Ustawa z dnia 20 lutego 1993 r. zmieniająca ustawe o uznaniu za nieważne orzeczeń wydanych wobec osób represjonowanych za działalność na rzecz niepodległego bytu Państwa Polskiego, Dz.U. 1993, nr 36, poz. 159.

W celi śmierci z „Zapora”, „Nasz Dziennik” [online], 9 III 2013 [dostęp: 28 V 2019], dostępny w internecie: <https://naszdziennik.pl/polska-kraj/26272,w-celi-smierci-z-zapora.html>.

[Władysław Góra], „Biuletyn Informacji Publicznej Instytutu Pamięci Narodowej” [online, dostęp: 28 V 2019], dostępne w internecie: <https://katalog.bip.ipn.gov.pl/informacje/127675>.

Wyrok Wojskowego Sąu Rejonowego w Warszawie z dnia 23 X 1948 r. skazujący na karę śmierci Adama Gajdka, działacza Zrzeszenia ,Wolność i Niezawistość” (Znak akt Sr. 1188/48), oprac.

A. Zagórski, „Zeszyty Historyczne WiN-u”, 3(1993), dok. 4-5.

Zawołać po imieniu. Księga kobiet - więźniów politycznych 1944-1958, t. 1, oprac. B. Otwinowska, wsp. T. Drzal, Nadarzyn 1999.

\section{OPRACOWANIA}

Aparat bezpieczeństwa publicznego w walce z polskim podziemiem niepodległościowym, „Pamięć i Sprawiedliwość", 1(2004).

Balbus T., Jan Tataruch, w: Konspiracja i opór społeczny w Polsce 1944-1956. Stownik biograficzny, t. 2, Kraków-Warszawa-Wrocław 2004.

Balbus T., O Polskę Wolna i Niezawista (1945-1948). WiN w potudniowo-zachodniej Polsce (genezastruktury - działalność - likwidacja - represje), Kraków-Wrocław 2004.

BonusiakW., Więzienie na Zamku w Rzeszowie w latach 1944-1956, „Studia Rzeszowskie”, 1(1995).

Frazik W., Operacja „Cezary” - przegląd wątków krajowych, w: „Zwyczajny” resort. Studia o aparacie bezpieczeństwa 1944-1956, red. K. Krajewski, T. Łabuszewski, Warszawa 2005.

Frazik W., Siatki wywiadowcze Obszaru Południowego Zrzeszenia ,Wolność i Niezawisłość”, w: W sieci. Powojenne polskie siatki wywiadowcze (AK-NIE-DSZ-WiN, PSZ) w latach 1944-1955, Warszawa 2016.

Hermański S., Wróblewski T., Piotr Śmietański (1899-1950), kat z Mokotowa, „Aparat Represji w Polsce Ludowej 1944-1989”, 1(2012). 
Kamiński Ł., Lingua securitatis, w: Wokót teczek bezpieki-zagadnienia metodologiczno-źródtoznawcze, red. F. Musiał, Kraków 2006.

„Kapitulacja” Łukasza Cieplińskiego, oprac. W. Frazik, „Zeszyty Historyczne WiN-u”, 19-20(2003).

Konspiracja i opór społeczny w Polsce 1944-1956. Stownik biograficzny, t. 2, Kraków-WarszawaWrocław 2004.

Łaszczewski T., Tataruch Jan Kazimierz, w: Małopolski słownik uczestników działań niepodległościowych, t. 9, red. T. Gąsiorowski i in., Kraków 2003.

Nowotnik N., Święto „Żotnierzy Wyklętych”- kolejny powrót bohaterów, „Kombatant”, 3(2014).

Ostasz G., Okręg Rzeszowski Zrzeszenia „,Wolność i Niezawistość”. Model konspiracji, struktura, dzieje, Rzeszów 2006.

Pisuliński J., Adam Gajdek (1915-1949), w: Konspiracja i opór społeczny w Polsce 1944-1956. Stownik biograficzny, t. 2, Kraków-Warszawa-Wrocław 2004.

Stańko A., Gdzie Karpat progi... Armia Krajowa w powiecie dębickim, wyd. 2, Warszawa 1990.

W sieci. Powojenne polskie siatki wywiadowcze (AK-NIE-DSZ-WiN, PSZ) w latach 1944-1955, Warszawa 2016.

Wokół teczek bezpieki - zagadnienia metodologiczno-źródtoznawcze, red. F. Musiał, Kraków 2006.

Wójcik Z.K., Łukasz Ciepliński, w: Konspiracja i opór społeczny w Polsce 1944-1956. Stownik biograficzny, t. 2, Kraków-Warszawa-Wrocław 2004.

Wójcik Z.K., Mieczysław Marian Kawalec (1916-1951), w: Konspiracja i opór społeczny w Polsce 1944-1956. Słownik biograficzny, t. 2, Kraków-Warszawa-Wrocław 2004.

Zblewski Z., Okręg Krakowski Zrzeszenia „,Wolność i Niezawisłość” 1945-1948. Geneza, struktury, działalność, Kraków 2005.

Zrzeszenie „Wolność i Niezawisłość” w dokumentach, t. 6: Cztery Zarzady Główne WiN przed sadami PRL. Noty biograficzne ważniejszych postaci wymienionych w tomach I-VI, cz. 2-3, oprac. A. Zagórski, Wrocław 2000.

„Zwyczajny” resort. Studia o aparacie bezpieczeństwa 1944-1956, red. K. Krajewski, T. Łabuszewski, Warszawa 2005.

\title{
"HE WAS FAR FROM HATRED, INCLUDING TOWARDS HIS TORTURERS..." THE CASE OF ADAM GAJDEK AS AN EXAMPLE OF A COMMUNIST CRIME
}

\begin{abstract}
Adam Gajdek took part in the Polish campaign of September 1939. He fought in the 3rd Rifle Regiment in Bielsk. In 1940, under the codename "Olek", he joined the Union of Armed Struggle and later the Home Army. After the incursion of the Soviet army into the Polish territory he remained underground. He took part, among other things, in the failed attack on the prison in the Rzeszów castle on 7-8 October 1944. In early 1947, he joined the Freedom and Independence. In April 1947 he became an executive of the spy network codenamed "Instytut Bakteriologiczny" created in late 1946. His direct superior was Mieczysław Kawalec, the head of the Information Department of the 4th Main Board of the Freedom and Independence. Adam Gajdek was arrested on 17 October 1947 by the officers of the Kraków division of the Ministry of Public Security. The preliminary investigation
\end{abstract}


was conducted in Kraków and later he was taken to the detention of the Ministry of Public Security in Warsaw. In the autumn of 1948 his case was transferred to Military District Court in Warsaw. On 23 October 1948 he was sentenced to death. The Supreme Military Court dismissed the appeal and President Bolesław Bierut did not pardon the officer. Adam Gajdek was executed on 14 January 1949 in the prison in Rakowiecka Street in Warsaw.

Keywords: Adam Gajdek, communist crimes, Stalinism, the Freedom and Independence

Translated by Hubert Kowalewski 